\title{
Una Haġadá sefardí burlesca de Purim: Edición y estudio
}

\author{
Elena Romero \\ ILC-CCHS, CSIC, Madrid
}

En el presente artículo se edita y estudia el texto hebreo-arameo y judeoespañol de la llamada Haġadá šel Purim (Jerusalén 1894), publicada por el librero de Jerusalén Šelomó Yisrael Šereślí y traducida al judeoespañol por Ben-Ŝiyón Taragán, y se lleva a cabo la comparación in extenso de tal versión con la de su original hebreo-arameo: la llamada Haġadá lelel šikorim, de Hirsch Sommerhausen (Niederwehren, Baviera, 1781 - Bruselas 1853), publicada por primera vez en Lemberg en 1847. Se trata de una parodia de la Hagadá de Pésah dedicada a la festividad de Purim, en la cual, sin ninguna especial intención satírica y sólo paródica, se hace una magnífica exaltación del vino frente a todas las demás bebidas alcohólicas.

Palabras Clave: Literatura judeoespañola aljamiada; literatura asquenazí; parodias; edición de textos sefardíes; Hag̉adá; Pésah; Purim; Šelomó Yisrael Šereślí; Ben-Ŝiyón Taragán; Hirsch Sommerhausen.

A Sephardic Purim Burleske HagGadah: Edition and Study.- This comparative study provides a detailed analysis of two Purim texts that parody the Passover Hagadah. The original Hebrew-Aramaic text, Haġadá lelel šikorim, by Hirsch Sommerhausen (Niederwehren, Bavaria, 1781 - Brussels 1853), was first published Lemberg in 1847. The second, which was derived from the first is Hagadá šel Purim (Jerusalem 1894), published by the Jerusalem bookseller Šelomó Yisrael Šereślí and translated into Judeo-Spanish by Ben-Ŝiyón Taragán. The texts, dedicated to Purim, without any special satirical intention provide a parody exalting wine above all other alcoholic beverages. The analysis presents an edited study of the second text with references to the original text and specifically highlights variations between the two.

KeYwords: Judeo-Spanish Literature; Ashkenazic Literature; Parodies; Edition of Sephardic Texts; Pesạ̣ Haggadah; Purim, Šelomó Yisrael Šereśli; Ben-Ŝiyón Taragán; Hirsch Sommerhausen.

* El presente artículo se ha elaborado en el marco del proyecto de investigación del Plan Nacional I+D+I: «Sefarad siglo XXI (2009-2011): Edición y Estudio Filológico de Textos Sefardíes» (SGPI, MICINN, FF2009-10672 [subprograma FILO]).

elena.romero@cchs.csic.es 


\section{EstAdO DE LA CUESTIÓN}

En el XVII Congreso de Estudios Sefardíes celebrado en la Universidad de Bar-Ilan (Tel Aviv, 2-4 julio de 2012), Ángel Berenguer Amador y yo misma hemos presentado una comunicación, titulada « Viva el vino y quien lo bebe 'ad de-ló yedá‘!: una Haġadá burlesca de Purim», en la cual nos hemos ocupado de hacer una primera presentación de la llamada Haġadá šel Purim, publicada en Jerusalén en 1894 (abrev. J894) por el

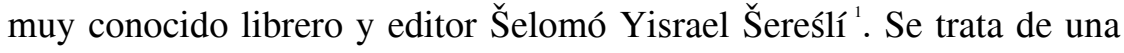
más -y probablemente no la última- que añadir al magnífico estudio de Eliezer Papo sobre el tema.

Resumamos algunos de los imprescindibles datos expuestos en nuestra citada comunicación. La obra que nos ocupa es una parodia de la Hagadá de Pésah dedicada a la festividad de Purim, en la cual, sin ninguna especial intención satírica y sólo paródica, se hace una magnífica exaltación del vino frente a todas las demás bebidas alcohólicas.

Dicha Haġadá aparecía ya mencionada por Romero en Creación (p. 68), donde se atribuía a Ben-Ŝiyón Taragán la traducción al judeoespañol que acompaña al burlesco texto hebreo-arameo.

También en nuestra mencionada comunicación precisábamos la fuente original del texto hebreo-arameo -y por tanto del judeoespañol- de esta paródica Haġadá: la llamada Haġadá lelel šikorim, de Hirsch Sommerhausen (Niederwehren, Baviera, 1781 - Bruselas 1853), publicada por primera vez en Lemberg en 1847, y de cuyas ediciones se ocupa Israel Davidson en Parody (p. 176): la citada de Lemberg 1847 y allí mismo en 1854; Cracovia en 1878; y Varsovia en 1885, las cuales incluyen otros textos paródicos. Pero además en su bibliografía (cap. XIV, núm. 307, pp. 247-249) señala Davidson que la Hagadá lelel šikorim tuvo varias ediciones independientes: Bruselas 1842, Hamburgo 1844 y Ámsterdam 1849, todas ellas con traducción de algunos

\footnotetext{
${ }^{1}$ Uso fotocopia del ejemplar de la NLI S23V14901. En la citada comunicación nos ocupábamos, entre otras cosas, del contenido misceláneo del libro, que no hace falta repetir aquí. Pero sí quiero precisar ahora, que, como luego diré, he podido manejar el texto completo, que precede a la portada del libro y en una hoja doblada y de tamaño mayor al resto la llamada Ketuḅá lePurim, es decir, la versión en hebreo-arameo de la ketubá burlesca de Amán. Paralelamente, en la edición de Šereślí figura el texto judeoespañol en prosa de la Ketuḅat bat Hamán harašá‘ (pp. 31-38).
} 
pasajes del texto hebreo-arameo al alemán; Viena 1850 - que es la edición que uso para mi estudio (abrev. V850) - y Liorna 1889, en las que se ha suprimido tal traducción al alemán; y finalmente, Argel 1890, en versión abreviada y con traducción al judeoárabe.

Es interesante subrayar que Davidson no conoció nuestra versión con traducción al judeoespañol.

Pasajes de la Hagadá lelel šikorim se publican en la antología de Purim de Philip Goodman (cap. XVI, pp. 330-356), tras un resumen de lo que dijera Davidson en su citado libro. Tales pasajes corresponden a los siguientes parágrafos que luego numero: 1 («Ha ḥamrá»), 2 («Ma ništaná»), 5 («Amar rabí ‘Aquibá»), 6 («Baruj haMacom»), 7 («Hajam»), 10 ( $2^{\circ}$ párrafo «Yajol meróš ḥodeš»), 11 («Miteḥilá»), 12 («Baruj šomer») y 13 («Hu hayayin»).

Otros fragmentos aparecieron en el artículo de Arie Gabhart «Hitpatehut» dedicado específicamente a esta Hagadá. Aquí figuran (p. 135) las siguientes partes del texto (remito siempre a mis números): las primeras palabras de 1 («Ha ḥamrá»), frases sueltas de 2 («Ma ništaná»), el final de 3 («'Abadim»), entero el 4 («Ma'asé berabí Garg̉uerán»), una frase de 29 («Bejol dor vador») y 38 con la frase de cierre de la Haǵadá.

Según decíamos en nuestra aludida comunicación, ésta debía entenderse como un adelanto de un futuro trabajo en el que se llevara a cabo la comparación in extenso de la versión hebreo-aramea del libro de Šereślí con la de Sommerhausen, así como una edición completa del texto judeoespañol. Este es el objetivo del presente artículo.

\section{PRESENTACIÓN FORMAL Y ORGANIZACIÓN DE LA OBRA}

En lo formal, la Hagadá se presenta como sigue: los párrafos en hebreo-arameo (en letra cuadrada no vocalizada, abrev. J894h) van seguidos de los correspondientes en judeoespañol (en letra raší, abrev. J894j), presentando ambos en letra cuadrada de cuerpo mayor la primera palabra de cada párrafo (las marco en negrita).

En cuanto a su organización, el texto va precedido del título Hagadá šel Purim (p. 3) y se inicia directamente con las palabras «Ha ḥamrá» (núm. 1), omitiéndose las bendiciones previas de la Haǵadá tradicional. Se sigue 
luego parodiando dicho texto -si bien en ocasiones con formulaciones más breves-, desde «Ma ništaná» (núm. 2) hasta el párrafo que se inicia «Beŝet» (núm. 32). Se omiten a continuación todas las bendiciones sobre los alimentos simbólicos de la cena pascual así como el largo «Birkat hamaźón» ('Bendición de los alimentos'), para pasar directamente al párrafo que comienza con «Šefoj» (núm. 33). Se abrevian luego algunos pasajes intermedios hasta llegar al texto de la letanía «Ki le 'olam ḥasdó» ('Que su misericordia es eterna'), el cual ya no se traduce al judeoespañol, acabando aquí dicha versión, lo que pone también fin a mi edición ${ }^{2}$.

\section{SISTEMA DE EDICIÓN}

Segmento el texto de la Hagadá en 38 parágrafos, cada uno de los cuales puede constar de las siguientes cuatro partes.

1) Para que el lector pueda calar mejor en la parodia textual, en el primer párrafo incluyo entre corchetes una versión judeoespañola de la Haġadá tradicional: la publicada por el impresor salonicense Sa'adi Haleví, en su Haġadá šel Pésah que vio la luz en Salónica en $1872^{3}$ (abrev. S872). En tal edición, tanto el texto hebreo-arameo como el judeoespañol aparecen en letra cuadrada vocalizada; respeto mayoritariamente las vocalizaciones de la aljamía y corrijo sin avisar los errores obvios. Como el texto sefardí, por apegarse tradicionalmente al hebreo-arameo, resulta en ocasiones bastante abstruso, en notas lo «traduzco» al español. Abrevio (con puntos suspensivos entre paréntesis y tanto en texto como en notas) aquellos pasajes en que el texto paródico poco o nada tiene que ver con el tradicional.

2) En el segundo párrafo figura el texto paródico en hebreo-arameo (J894h). Para que el no hebraísta pueda leerlo, lo transcribo a continuación en caracteres latinos.

${ }^{2}$ Como en V850, en J894h la parodia continúa con la mencionada letanía «Ki le'olam hasdó» (pp. 26-27) y los parágrafos que comienzan «Nišmat» (p. 27), «Veilu finu» (p. 28), «Šojén» (p. 28), «Ubemac·halot» (p. 29) y «Yištaḅah» (p. 29) al que, a modo de cierre se añade (núm. 38) la frase habitual que, a pesar de no estar traducida al judeoespañol, sí he mantenido, así como una versión paródica del texto arameo de «Ḥad gadiá» (pp. 29-31). Más amplio es el texto de V850 que, además de los parágrafos señalados, añade al final varios a modo de piyutim alefáticos y acrósticos, y también una parodia de «Eḥad mi yodea'».

${ }^{3}$ Uso fotocopia del ejemplar del YIVO, manco de las hojas finales. 
3) En el tercer párrafo transcribo de la aljamía el correspondiente texto judeoespañol (J894j).

4) Y finalmente, siguen mis comentarios (separados entre sí por punto y guión, y separados los párrafos en que se segmenta el texto) en los que señalo las diferencias entre J894h y el texto original de la Hagadá lelel šikorim, de Hirsch Sommerhausen, así como las singularidades del texto judeoespañol en relación con el hebreo-arameo que traduce -J894h-, y también con V850. Las diferencias textuales que provocan comentarios se marcan en los textos hebreo (y su transcripción) y judeoespañol de apartados 2 y 3 con un cerillo volado ( $)$, el cual implica remisión a este apartado 4 .

No es éste el lugar adecuado ni es mi función analizar el complejo texto paródico de Sommerhausen, del que, según creo, nadie se ha ocupado a fondo ni se ha hecho una edición crítica, y del que con razón decía Davidson (pp. 110-111) que se trata de una de las más inteligentes imitaciones litúrgicas conocidas en la literatura hebrea. Sólo diré que sus engranajes con el texto de la Hagadá tradicional no sólo se plasman en el mantenimiento mayoritario de las palabras que abren y cierran los parágrafos de éste, sino en el uso de voces y de formulaciones iguales o similares, en una magnífica imitación del sistema de argumentación rabínico que en la Hagadá tradicional ocupa largos pasajes, así como en aducir numerosos versículos bíblicos -y no sólo los ya insertados en la Hagadá tradicional- que encajan a la perfección con las nuevas frases paródicas.

Los versículos bíblicos que figuran en la parodia proceden de muy diversos libros bíblicos, que indico a continuación de mayor o menor uso, remitiendo entre paréntesis a los páragrafos en los que aparecen. Son abundantes las citas del libro de Ester: 1:7 (14), 1:8 (12), 2:17 (15), 4:14 (28), 4:16 (3 y 5), 8:13 (28), 8:16 (21 y 22), 9:7-10 (18), 9:14 (20), 9:19 (3), 9:22 (5, 10, 16-17 y 27), 9:27 (10 y 29), 9:28 (11), 9:31 (29) y 10:2 (15), amén de los pasajes aludidos en núm. 23, rememorando diversos episodios narrados en dicho libro. Son también numerosas las citas del libro de Salmos, bien versículos sueltos -9:19 (14), 16:5 (16), 18:51 (14), 60:1 (15), 79:6-7 (33), 81:11 (10), 104:15 (2, 26), 106:1 (14), 116:13 (14), 132:15 (16), 136:24 (3) y 141:5 (14)-, bien en lotes, que son los varios que corresponden a la 
oración del Halel -113:1-9 (31), 114:1-8 (32), 115:1-7 (34), 116:18 (35), 116:12-14 (36), 116:18-19 (36) y 117:1-2 (37)-. Les siguen en número las citas de Eclesiastés: 3:4 (28), 3:19 (27) y 9:7 (14, 16 y 26-27). Con sendos dos versículos están presentes Deuteronomio $-8: 3$ (26) y 31:19 (10)-, 1Reyes $-1: 5$ (14) y 4:20 (16)-, Isaías $-5: 22$ (14) y 12:3 (28)- y Proverbios $-15: 15$ (16) y 16:31 (14). Y con uno figuran otros varios libros bíblicos: Éxodo 11:5 (20); Jueces 9:12 (15); 2Samuel 22:51 (14); Jeremías 25:27 (27); Ezequiel 16:12 (15); Habacuc 2:16 (27); Zacarías 10:3 (15); Cantar de los cantares 4:12 (13); Nehemías 8:10 (26); y lCrónicas 29:11 (14); amén de una alusión a Génesis 25:8 (3).

Para la comparación textual, en un principio me he servido de la edición de dicha Haġadá de Sommerhausen puesta por Google a disposición de los estudiosos ${ }^{4}$. Tal ejemplar, carente de portada, lleva una nota manuscrita en letras latinas en la que se precisa la edición: la arriba citada de Viena 1850 (abrev. V850), en donde la Haġadá ocupa las hs. 1b-9b. El texto está vocalizado, vocalización que sigo mayoritariamente en mis transcripciones. El citado ejemplar está manco de las primeras hojas, iniciándose el texto paródico (h. 2a) con el parágrafo «"Abadim» (núm. 3 infra). He podido completar tal edición gracias a la generosidad de Jacob Hagüel, quien me ha permitido fotocopiar el ejemplar de su biblioteca privada, lo que le agradezco de todo corazón.

He aquí un resumen del texto de portada (el pie de imprenta en caracteres latinos):

Haġadá lelel šikorim / [...] / venosaf 'aléah / Séfer Habacḅuc hanabi / [...] / Wien 1850 / Druck von Adalbert della Torre / [...].

Amén de las diferencias entre los tres textos -V850, J894h y $\mathrm{J} 894 \mathrm{j}$ - que anoto en mis comentarios y que luego recojo (aprt. 5), debo advertir que las mayores diferencias aparecen en la parte final del texto, donde, como ya he advertido (nota 2), en J894h/j se han omitido una serie de pasajes y poemas que rematan el texto paródico de V850 (hs. 7a-8a), y tampoco aparecen en J894h/j la parodia

\footnotetext{
${ }^{4}$ El ejemplar pertenece a la Bibliotheca Regia Monacensis (actualmente Bayerische Staatsbibliothek de Munich) A. hebr. 698.
} 
del poema Ehad mi yodea' que en la edición vienesa (hs. 8a-9a) precede a la de Had gadiá (hs. 9a-b), ni el texto burlesco titulado Séfer Habacbuc hanabí. Recordemos, sin embargo, que la versión judeoespañola -que es la que ahora me ocupa y con la que remato mi edición-acaba abruptamente antes de esos pasajes finales, por lo que el lector no va a advertir tales ausencias.

Cabe también repetir aquí lo que Berenguer y yo misma señalábamos en nuestro estudio arriba citado: que no podemos afirmar que la versión burlesca de la Haġadá lelel šikorim del muy asquenazí Hirsch Sommerhausen que llegara a los muy sefardíes Šereślí y su colaborador Taragán de la Jerusalén de 1894 fuera justamente la que hemos manejado de Viena 1850, lo cual, sin embargo, no sería imposible, por tratarse de una edición que vio la luz en ámbitos sefardíes. Pero no he podido consultar la edición de Liorna de 1889, publicada sólo cinco años antes que la nuestra de 1894, y en consecuencia ignoro si en ella se encuentran ya los cambios que luego iré señalando.

Marco con barras y números volados y en negrita las páginas de la edición de Jerusalén; y en negrita las palabras que aparecen en cuerpo mayor. Y finalmente, las palabras de difícil comprensión de J894j se traducen entre corchetes en el propio texto, completándose el artículo con una lista de palabras explicadas en la que se precisan las etimologías y se remite al parágrafo o a la nota donde se traducen o se comentan. No tengo aquí en cuenta el léxico de S872, ya que los pasajes se traducen en las notas. 


\section{EDICIÓN DEL TEXTO}

\section{${ }^{13}$ Haġadá šel Purim \\ מוזגין כוס תשיעי ומתחילים לאמר ההגדה}

Moźeguín kos teši ‘í umathilim lomar haHag̉adá ${ }^{5}$ ['Sirven el vaso noveno y empiezan a decir la Haġadá'] ${ }^{6}$

[Cadéš: Hinchirán los vaśos de vino y dirán la Haġadá (S872 h. 9a).]

1.- [Este pan de la afriición que comieron muestros padres en tiera de Ayifto. Todo el que tuviense hanbre entre y coma; todo el que tuviense de menester entre y pascue. Este año aquí, a el año el vinién en tiera de Yisrael; este año aquí, siervos; a el año el vinién en tiera de Yisrael, hijos foros (S872 h. 9a ${ }^{7}$.]

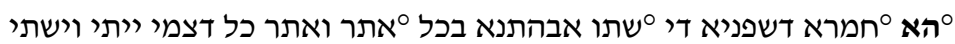

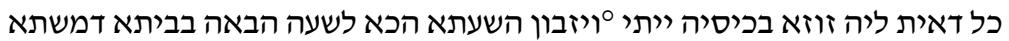
השעתא הכה לשעה הבאה שכוזה שכורין.

${ }^{\circ}$ Ha ${ }^{\circ}$ ḥamrá de-šapaña di ${ }^{\circ}$ šatú abhataná bejol ${ }^{\circ}$ atar veatar. Kol de samí yetí veyiští; kol de it leh źuźá bejisé yetí ${ }^{\circ}$ veyiźbón. Haša aatá hajá, leša ‘á haḅaá bebetá de-mištá; haša ‘atá hajá, leša ‘á haḅaá šikorín.

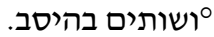

${ }^{\circ}$ Vešotim beheseb.

${ }^{5}$ En V850 el título es el esperado de Hagadá lelel šikorim, a lo que sigue un texto precedido del epígrafe «Simán leséder Purim» ('Señal del orden de Purim') en el que se recomienda en general «šeté vaejol, ejol ušté» ('bebe y come, come y bebe') y al triste que coma y beba «'ad lo tedá' ben yamín lismol» ('hasta que no distingas entre la derecha y la izquierda'). Debajo aparece un grabado en el que un varón con largos ropones de rabino ofrece una gran copa a un hombre vestido sencillamente y que se apoya en un cayado. Sigue en V850 un texto más breve que el de J894h y con un verbo distinto: «Magbihín kos teši “í» ('Alzan el noveno vaso').

${ }^{6}$ Recordemos que en la cena ritual de Pascua es obligado beber cuatro vasos de vino y no los que aquí se indican. La explicación de los vasos que se deben beber, que aumentan a 10, según vemos en el parágrafo 3, la encontramos en núm. 20 infra. Salvo en un caso que luego señalo, no se traducen al judeoespañol la mayoría de tales indicaciones que también aparecen en la Hagadá tradicional a modo de guía para el «oficiante».

7 'Este es el pan de la aflicción que comieron nuestros padres en tierra de Egipto. Todo el que tiene hambre venga y coma; todo el que tiene de menester venga y pascue. Este año aquí, el año que viene en tierra de Israel; este año aquí, siervos; el año que viene en tierra de Israel, libres'. 
${ }^{\circ}$ Este el ${ }^{\circ}$ vino ${ }^{8}$ de España que ${ }^{\circ}$ bebieron muestros padres en todo ${ }^{\circ}$ lugar y lugar. Todo el que tiene sed venga y beba; todo el que tiene ducados en su bolsa venga y ${ }^{\circ}$ merque. Esta hora aquí, a la hora el vinién ${ }^{9}$ en caśa de el convite; esta hora aquí, a la hora el vinién borachos.

En V850 (h. 1b) כהא Kehá 'Como éste (es)', Ke inicial que no aparece en J894h/j.- En V850 חמרא דשמפניה hamrá de-šampaña, quizá aludiendo al champán, en lugar del חמרא דשפניא hamrá de-šapaña de J894h, formulación que ha llevado al traductor sefardí a escribir «vino de España»; claro que no puedo afirmar que el cambio en el texto arameo no fuera en este caso intencionado por parte del editor de Jerusalén

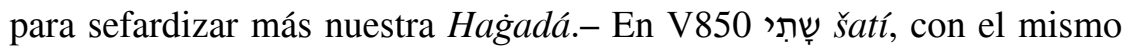
significado.- En V850 אתר ואתר atrá veatrá, en lugar de atar veatar de J894h, con el mismo significado de 'lugar'.- En V850 escrito ויזבין veyiźbín, con el mismo significado.

En V850 (h. 1b) la indicación es solamente ושותים Vešotim 'Y beben' en lugar del ושותים בהיסב Vešotim beheseb 'Y beben recostados' de J894h, cuya traducción se omite en $\mathrm{J} 894 \mathrm{j}$; recuérdese que reclinándose sobre el codo izquierdo es como se deben beber las copas prescritas en Pascua.

\section{סוכאן הבן שואל}

'Vekán habén šoel ['Y aquí el hijo pregunta']

2.- ¿¿Cuánto fue demudada la noche la esta más que todas las noches? Que en todas las noches no nos entiñentes afilú veź una, y la noche la esta dos većes. Que en todas las noches nos comientes ḥaméŝ o maŝá, y la noche la esta todo es maŝá. Que en todas las noches nos comientes resto de vedruras, y la noche la esta lichuga. Que en todas las noches nos comientes y bebientes, quien asentados y quien arescovdados, y la noche la esta todos nos arescovdados (S872 h. 9b) ${ }^{11}$.]

\footnotetext{
${ }^{8}$ Es decir, este es el vino; la ausencia del presente del verbo copulativo, sustituida generalmente por un pronombre personal, es normativa en arameo y en hebreo, como lo refleja la traducción literal en judeoespañol. No vuelvo a comentar tal fenómeno.

${ }^{9}$ Vinién es forma apocopada de viniente, es decir, la hora que viene. Se trata de traducciones literales en judeoespañol de participios de presente arameos y hebreos, que no vuelvo a comentar.

${ }^{10}$ Tal interpolación no aparece en S872.

${ }^{11}$ ¿En qué se diferencia esta noche de todas las noches? Que todas las noches no mojamos (los alimentos) ni siquiera una vez, y esta noche dos veces. Que todas las noches comemos pan
} 


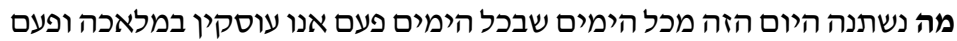

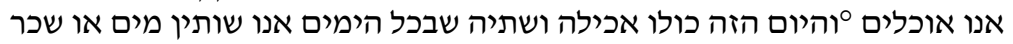

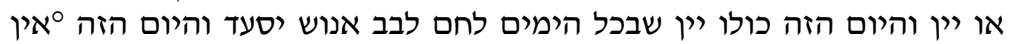

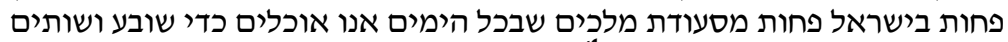

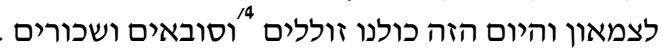

¿Ma ništaná hayom haźé mikol hayamim? Šeḅejol hayamim pá ‘am anu 'osequim biml'ajá upá‘am anu ojelim, vehayom haźé kuló ajilá ušetiyá. Šeḅejol hayamim anu šotim máyim o šejar o yayin, vehayom haźé kuló yayin. Šeḅejol hayamim léhem lebab enóš yis ‘ad, vehayom haźé ${ }^{\circ}$ en paḥut beYisrael paḥut mise“udat melajim. Šeḅejol hayamim anu ojelim kedé sobea 'vešotim leŝimaón, vehayom haźé kulanu źolelim vesobeím vešikorim.

¿Cuánto fue demudado ['diferente'] el día el este más que todos los días? Que en todos los días veź ${ }^{12}$ nos entremetidos ['ocupados'] en obra ['trabajando'] y veź nos comientes ${ }^{13}$, 'y el día el este todo él comer y beber. Que en todos los días nos bebientes agua o raquí o vino, y el día el este todo él vino. Que en todos los días pan corazón de varón asufrirá ${ }^{14}$ [Sal 104:15], y el día el este ${ }^{\circ}$ non manco en Yisrael de se 'udá ['banquete'] de reyes. Que en todos los días nos comientes por hartura y bebientes por sed, y el día el este todos nos tragones y embriagos ['ebrios'] y borachos.

En V850 (h. 1b) no aparece tal conjunción - ve- 'y' de J894h/j, ni אין פחות משר en pahut beYisrael belí se 'udat melajim lit. 'no hay ningún bajo [en la escala social, pobre] de Israel sin un ágape אין פחות בישראל אי en pahut beYisrael pahut mise'udat melajim, repetición de paḥut que puede explicarse por mero error de imprenta; en $\mathrm{J} 984 \mathrm{j}$ el problema se resuelve con la frase «non manco en Yisrael de se "udá de reyes», que puede entenderse como 'ningún judío se queda sin un banquete regio'.

leudado o pan cenceño, y esta noche todo cenceño. Que todas las noches comemos variedad de verduras, y esta noche lechuga (= hierbas amargas). Que todas las noches comemos y bebemos, bien sentados, bien recostados, y esta noche todos nosotros recostados'.

${ }^{12}$ Es decir, a veces.

${ }^{13}$ Es decir, unas veces trabajamos y otras comemos.

${ }^{14}$ Es decir, es el pan el que sostiene (asufrirá) el corazón del hombre. 
סומוזגים כוס עשירי

'Umoźeguim kos 'asirí ['Y vierten el décimo vaso'] ${ }^{15}$

3.- [Siervos huimos a Par‘ó en Ayifto y sacomos Yy, muestro Dio, de ahí con poder huerte y con brazo tendido. Y, si no sacara el Santo, bindicho él, a muestros padres de Ayifto, aínda nos y muestros hijos y hijos de muestros hijos sojeftos huéramos a Par'ó en Ayifto. Y afilú todos nos sabios y todos nos entendidos ${ }^{16}$, todos nos sabientes a la Ley, encomendanza sobre nos por recontar en salidura de Ayifto. Y todo el que muchigua por recontar en salidura de Ayifto de cierto éste es alabado (S872 hs. 9b-10a) ${ }^{17}$.]

עבדים" היינו לאחשורוש בשושן ונמסרנו להמן הרשע וגם אסתר המלכה צותה

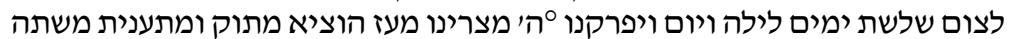

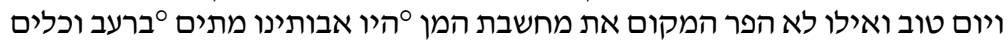

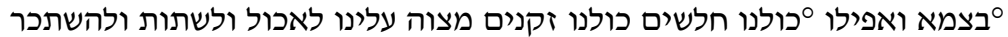

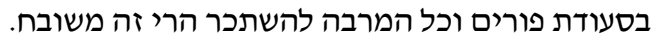

\begin{abstract}
'Abadim hayinu leAḥašveróš beŠušán venimsarnu leHamán harašá‘. Vegam Ester hamalká ŝivtá laŝum šelóšet yamim, laila veyom. «Vayifrequenu ${ }^{\circ} \mathrm{H}^{\prime}$ miŝarenu». Me'aź, hoŝí matoc; umita'anit, «mišté veyom tob». Veilu lo hefar haMacom et maḥašébet Hamán, 'hayú abotenu metim `berá ‘ab vejalim `beŝamá. Vaafilú ${ }^{\circ}$ kulanu halašim, kulanu źequenim, miŝvá 'alenu leejol velištot ulehištaker bise ‘udat Purim; vejol hamarḅé lehištaker haré źe mešuḅah.
\end{abstract}

Siervos fuimos a Aḥašveróš ['Asuero'] en Šušán ['Susa'] y mos entregó a Hamán ['Amán'] el malo. Tamién Ester la reina encomendó por ayunar tres días, noche y día [cfr. Ester 4:16]. ${ }^{15}$ «Y mos rigmió ['redimió'] 'H' ['Dios'] de muestros angustiadores» [Sal 136:24]. De fuerte, sacó dulce; y de afriición, «conviite y día bueno» [Ester 9:19]. Y, si non baldaba ['anulaba'] el Santo, bendicho Él, a pensamiento de Hamán,

${ }^{15}$ Vid. lo dicho supra nota 6.

כלנו זקנים En otras versiones hebreas y judeoespañolas de la Haġadá se añade aquí 'todos nosotros ancianos', que sí aparece en el texto paródico.

17 'Siervos fuimos del Faraón en Egipto y nos sacó el Señor, nuestro Dios, de allí con mano fuerte y con brazo extendido. Y si no hubiera sacado el Santo, bendicho Él, a nuestros padres de Egipto, aún nosotros y nuestros hijos y los hijos de nuestros hijos seguiríamos siendo esclavos del Faraón en Egipto. Y aunque todos seamos sabios, todos inteligentes, todos conocedores de la Ley, tenemos la obligación de narrar la salida de Egipto. Y todo el que redunde en narrar la salida de Egipto ciertamente es digno de alabanza'.

${ }^{18}$ Vid supra y nota 4. 
${ }^{\circ}$ eran muestros padres murientes en ${ }^{\circ}$ la hambre y atemantes ['exterminados'] en 'la sed. Y afilú ['incluso'] 'todos nos flacos, todos nos viejos, encomendanza sobre nos ${ }^{19}$ por comer y por beber y por enborachear en se 'udá de Purim; y todo el que muchigua ['abunda'] por enborachear de cierto éste alabado.

En V850 (h. 2a) no aparece la conjunción ilativa inicial.- En el versículo de Sal 136:24 citado no figura el nombre de Dios, que sí aparece abreviado mediante "Yy en V850 y mediante ה' en J894h/j.En V850 (h. 2a) הרי אבוינו haré abotenu 'ciertamente nuestros padres' en lugar de היו אבותינו 'hubieran nuestros padres' de J894h/j.- En J894j se traduce la hambre y la sed, ambas palabras con artículo, pero en V850 la primera palabra está vocalizada ברעב berá 'ab 'en hambre', sin

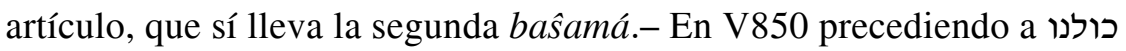
כלשים kulanu halašim 'todos somos débiles', se dice כולנו שבעים kanu sebe 'im 'todos estamos saciados', que no figura en J894h/j. Se trata de una alusión al texto bíblico de Gén 25:8 en donde, al referirse a la muerte de Abraham, leemos: «Vayámot Abraham beseba tobá, źaquén vesabea'»'Y Abraham murió en buena vejez, anciano y saciado'; en el juego paródico se plasman así las ideas de ancianidad y de saciedad, que quedan difuminadas en $\mathrm{J} 894 \mathrm{~h} / \mathrm{j}$, en donde, si bien se explicita la ancianidad-zequenim / viejos-, la saciedad hay que deducirla de las acciones que siguen.

4.- [Aconteció ma 'asé en ribịí Eli ‘éźer y riḅí Yehošúa ' y riḅí El ‘aźar hijo de 'Aźariá y riḅi ‘Aquibá y riḅí Tarfón, que eran arescovdados en almohadas de seda ${ }^{20}$ y eran recontantes en salidura de Ayifto toda aquea noche, hasta que vinieron sus talmidim y dijeron a ellos: «Muestros roḅisim, allegó tiempo de meldadura de queriat Šemá‘ de la mañana» (S872 h. 10a) ${ }^{21}$.]

${ }^{19}$ Es decir, se nos ha dado el mandato (encomendanza) de, se nos ha encomendado.

${ }^{20}$ Schwarzwald (p. 76) anota algunas de las versiones judeoespañolas que así traducen el topónimo Bené Berac, a saber: Salónica 1826 y 1876, y Viena ca. 1900, en tanto que en Viena 1851 se dice «cabezales de broslado».

${ }^{21}$ 'Lo sucedido con rabí Eli`éźer y rabí Yehošúa' y rabí El ‘aźar ben 'Aźariá y rabí 'Aquibá y rabí Tarfón, que estaban aposentados en Bené Berac y estuvieron narrando la salida de Egipto toda aquella noche, hasta que vinieron sus discípulos y les dijeron: «Rabinos nuestros, ha llegado la hora de la recitación de la (oración de la) Šemá‘ de la mañana’. 
מעשה ברבי גרגרן ור' יינא סבא ורבי חמרן ורבי שכרן ־ורבי בקבוק שה שהיו

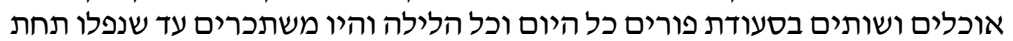

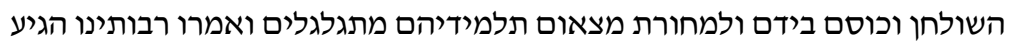

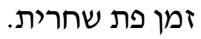

Ma'asé berabí Garg̉uerán ver’ Yená Sabá verabịi Hamrán verabí Šajrán ${ }^{\circ}$ veraḅi Bacḅuc šehayú ojelim vešotim bise ‘udat Purim kol hayom vejol halaila vehayú mištakerim 'ad šenaflú táḥat hašulhán vekosam beyadam. Ulemoḥorat maŝeum talmidehem mitgalguelim veamerú: «Raḅotenu, higguía“ źemán pat šaḥarit».

Ma'asé ['Lo sucedido'] en rabí ['rabí'] Gargiuerán ['Tragón'] y rabí Yená $^{22}$ ['Vinatero'] Sabá ['el Viejo'] y rabịi Hamrán ['Vinoso'] y raḅí Šajrán ['Borracho'] ${ }^{\circ}$, que eran comientes y bebientes en se 'udá de Purim todo el día y todo [sic] la noche, y eran enboracheándosen hasta que se cayeron debajo de la meśa y sus vaśos en sus manos ${ }^{23}$. Y a la mañana los toparon sus talmidim arodeándosen ${ }^{24}$ y dijeron: «Muestros señores ḥajamim ['maestros'], allegó tiempo de se ‘udá de la mañana».

Según el texto tradicional, tanto en V850 (h. 2a) como en J894h los rabinos -cuyos nombres aquí son una parodia de los que aparecen en el texto tradicional- son cinco, que quedan reducidos a cuatro en $\mathrm{J} 894 \mathrm{j}$, donde se prescinde del último rabí Bacbuc 'rabí Botella'.

5.- [Dijo ribịi El'aźar hijo de 'Aźariá: «De cierto yo como de idad de setenta años y no tuve źejut que se dijera salidura de Ayifto en las noches, hasta que darsó hijo de Źomá que ansí diće el pasuc: "Porque membres a día de tu salida de tiera de Ayifto todos días de tus vidas": días de tus vidas, los días; todos los días de tus vidas, las noches». Y hajamim dićientes: «Días de tus vidas, el mundo el este; todos días de tus vidas, por traer a días de el mašíaḥ» $\left(\mathrm{S} 872\right.$ h. 10b ${ }^{25}$.]

${ }^{22}$ Cuyo nombre hay que ponerlo en relación con el sí existente rabí Yanay.

${ }^{23}$ Es decir, manteniendo los vasos en sus manos.

${ }^{24}$ Es decir, revolcándose.

25 'Dijo rabí El'aźar ben 'Aźariá: «He aquí que soy como si tuviera setenta años y no he merecido que se hablara de la salida de Egipto por las noches hasta que interpretó Ben Źomá lo que se ha dicho (en el versículo): "Para que recuerdes el día de tu salida de la tierra de Egipto todos los días de tu vida" [Deut 16:3]: los días de tu vida (se refiere sólo a) los días; todos los días de tu vida (se refiere también a) las noches». Y (otros) sabios dicen: «Los días de tu vida es este mundo; todos los días de tu vida se refiere a que también hay que tener en cuenta los días del mesías'. 


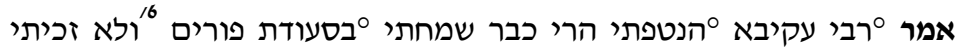

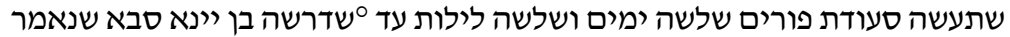

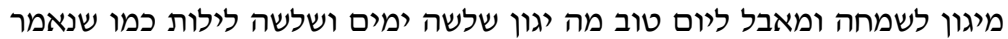

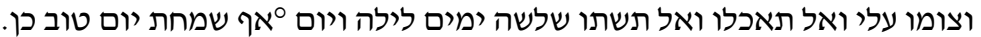

Amar ${ }^{\circ}$ rabịi 'Aquibá ${ }^{\circ}$ hanetifatí: «Haré kebar samahti ${ }^{\circ}$ bise ‘udat Purim veló źajiti šeta'asé se 'udat Purim šelošá yamim ušelošá lelot 'ad `šeḍerašah Ben Yená Sabá, šeneemar: "Miyagón lesimhá umeébel leyom tob"». ¿Ma yagón?: šelošá yamim ušelošá lelot, kemó šeneemar: «Veŝumu 'alay veal tojlú veal tištú šelošá yamim laila veyom», `af simhiat yom tob ken.

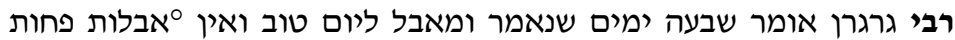
משבעה ימים וחכמים אינם אומרים כלום אלא אוכלים ושותים עד ימד ימות המשיח.

Rabịi Garg̉uerán omer: «Šibá yamim, šeneemar "umeébel leyom tob", veén ${ }^{\circ}$ abelot pahot mišibá ‘ yamim». Vehajamim enam omerim kelum, ela ojelim vešotim 'ad yemot hamašíah.

Diǰo ${ }^{\circ}$ rabịi 'Aquibá el ${ }^{\circ}$ netifatí: «De cierto ya me alegrí en ${ }^{\circ}$ se $u d a t$ Purim y no tuve źejut ['alcancé el mérito de'] que se haga se 'udat Purim tres días y tres noches hasta que ${ }^{\circ}$ daršó ${ }^{26}$ ['interpretó'] Ben Yená Sabá que ansí diće el pasuc ['versículo']: "De ansia a alegría y de limuño ['duelo'] a día bueno ['festivo']” [Ester 9:22]: ¿cómo ansia? ${ }^{27}$ : tres días y tres noches, como ansí diće el pasuc: "Y ayunad por mí y non comáš tres días noche y día" [Ester 4:16], 'tamién alegría de día bueno ansí».

Raḅi Garguerán dićién: «Siete días, que ansí diće el pasuc: "y de limuño a día bueno" [Ester 9:22], y non 'limuño manco ['menos'] de siete días ${ }^{28} \gg$. Y hajamim non dićen nada, salvo comen y beben hasta días de el mašíạ ['mesías']

Los dos párrafos aparecen unidos en V850 (h. 2a), pero separados en J894h/j.- En V850 רבי בקבוק rabí Bacbuc en lugar de רבי עקיבא rabi 'Aquibá de J894h/j; su denominación הנטפתי hanetifatí hay que ponerla en relación con hb. נט nétef 'gota' o con arm. nétef 'racimo de uvas'.- En V850 בשעודת besimhat 'en la alegría' en lugar de 'udat 'en

\footnotetext{
${ }^{26}$ Escrito דארשו d.r.š 'explicar, interpretar').

${ }^{27}$ Es decir «¿Qué quiere decir ansia?».

${ }^{28}$ Recuérdese que según el judaísmo el duelo (limuño) mayor tras la muerte de un ser cercano es de siete días.

${ }^{29}$ Es decir, hasta la llegada de los tiempos mesiánicos.
} 
el banquete' de J894h/j.- En V850 y en J894h שדרשה šederašah 'la/lo interpretó', pero en J894j se ha omitido el complemento.- J894j traduce כiteralmente la confusa frase de J894h, que en V850 es כמחת יום טוב ken simhat yom tob 'así es la alegría del día festivo'.

J894j traduce en singular lo que en V850 es אִבְלוֹת abelot 'duelos' -recuérdese que el texto de J894h no está vocalizado-, quizá por haber entendido el ות - ot final, no como la marca del pl. fm., sino como la terminación de los abstractos hebreos en נּ- - ut, es decir, abelut 'duelo'.

6.- [Bendicho el Criador que dio Ley a Yisrael, bendicho Él. Como escuentra cuatro hijos habló la Ley: uno sabio y uno malo y uno prenismo y uno que no sabe por demandar (S872 h. 10b) ${ }^{30}$.]

ברוך ׳המקום ברוך הוא ברוך שנתן המגילה לעמו ישראל ברוך הוא כנגד ארבעה

בנים דברה תורה אחד חכם ואחד שוא שוטה שנת ואחד תם ואחד שאינונו יודע לשתות.

Baruj ${ }^{\circ}$ haMacom, baruj Hu, baruj šenatán haMeguilá le ‘amó Yisrael, baruj Hu. Kenégued arḅa ‘á banim diḅerá Torá: eḥad ḥajam veeḥad šoté veeḥad tam veeḥad šeenó yodea ' lištot.

${ }^{17}$ Bendicho ${ }^{\circ}$ el Criador, bendicho Él, bendicho que dio la Meguilá ['el rollo de Ester'] a su pueblo Yisrael, bendicho Él. Como escuentra de ['delante de' o 'en relación a'] cuatro hijos habló la Ley: uno sabio y uno loco y uno pleniśmo ['simple'] y uno que no sabe por beber.

Así traduce siempre J894j lo que en los textos hebreos es המקום haMacom 'el Omnipresente' ${ }^{31}$.

7.- [Sabio, ¿qué él dićién?: «¿Qué el testamiento y los hueros y los juicios que encomendó Yy, muestro Dios, a vos?». También tú di a él como órdenes de la Pascua: «non espartirá después de corbán Pésạ maneras de manĵares» (S872 hs. 10b-11a) ${ }^{32}$.]

30 'Bendito sea Dios porque dio la Ley a su pueblo Israel, bendito sea. En relación con cuatro (tipos de) hijos habló la Ley: uno sabio, otro malvado, otro simple y otro que no sabe preguntar'.

${ }^{31}$ Vid. al respecto núms. 13 y 23-24 infra.

32 'El sabio ¿qué dice?: «¿Qué significan los testimonios, las leyes y las sentencias que os ha ordenado el Señor, nuestros Dios?» [Deut 6:20]. Ciertamente le instruirás en las normas de la Pascua (hasta la frase): «no se servirá ningún tipo de comida después de la cena de Pascua». 


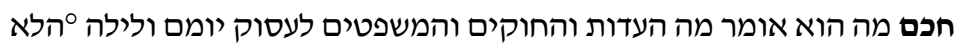

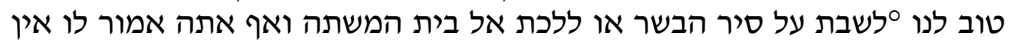
נפטרין עד הפסח ממקומן.

Hajam, ¿ma hu omer?: «¿Ma ha'edut vehahuquim vehamišpatim la 'asoc yomam velaila? ¿ ${ }^{\circ}$ Haló tob lanu ${ }^{\circ}$ lašébet 'al sir haḅasar o léjet el bet hamišté?». Veaf atá emor lo: «En niftarín 'ad haPésạ mimcomán».

Sabio, ¿qué él dićién?: «¿Qué los testamientos y los fueros y los juicios por entremeter ${ }^{33}$ día y noche? ${ }^{\circ}$ De cierto mejor a nos ${ }^{\circ}$ por estar sobre olla de la carne o andar a caśa del conṿite». Y tamién tú di a él: «Non se esparten ['se mueven'] hasta Pésah ['Pascua'] ${ }^{34}$ de sus lugares».

J894j traduce afirmativamente De cierto lo que en V850 y en J894h es una partícula interrogativa הלא haló ‘Acaso no?’.- En V850 (hs. 2a-b)

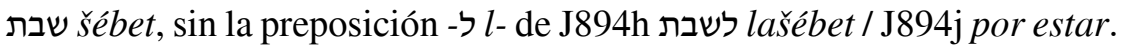

8.- [Malo, ¿qué él dićién?: «¿Qué el servicio el este a vos?». A vos y no a él, y porque se sacó a sí miśmo de la concluición ${ }^{35}$, cafró en la raíź. También tú haz escrujir a sus dientes y di a él: «Por esto hiźo Yy a mí en mi salir de Ayifto»: a mí y no a él, y si ḥuera ahí no ḥuera regmido $\left(\right.$ S872 h. 11a) ${ }^{36}$.]

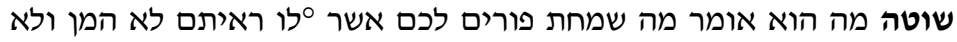

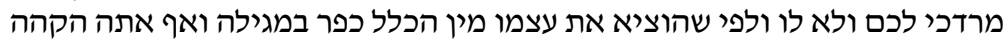

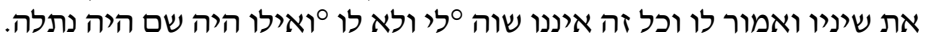

Šoté, ¿ma hu omer?: «¿Ma simhat Purim lajem, ašer ${ }^{\circ}$ lo reitem lo Hamán veló Mordejay?». Lajem veló lo; ulefí šehoŝí et aŝmó min hakelal, kafar baMeguilá. Veaf atá hec·hé et šinav veemor lo: «Vejol źe enenu šavé ${ }^{\circ} \mathrm{li}$ »: veló $l o$; ${ }^{\circ}$ veilu hayá šam, hayá nitlé.

${ }^{33}$ Es decir, para estar ocupados (entremeter) en ellos.

${ }^{34}$ Pésah (hb. פסח); recuérdese que tal fiesta se celebra un mes después de la fiesta de Purim.

${ }^{35}$ Sobre las distintas formas y grafías de la palabra que traduce hb. kelal 'conjunto' en las versiones sefardíes de la Haġadá, vid. SchwarzwaLd p. 119.

36 'El malvado, ¿qué dice?: «¿Qué es este rito para vosotros?» [Éx 12:26]. Para vosotros y no para él; y, ya que se excluyó a sí mismo del conjunto, pecó en lo principal. Ciertamente hazle rechinar los dientes y dile: «Por eso me hizo el Señor (prodigios) cuando salí de Egipto» [Éx 13:8]: a mí y no a él; y si hubiera estado allí, no se habría salvado'. 
Loco, ¿qué él dićién?: «¿Qué alegría de Purim a vos que ${ }^{\circ}$ no visteš no Hamán y no Mordejay ['Mardoqueo']?». 'A vos, a vos y non a él; y porque sacó a sí miśmo del kelal ['conjunto’], cafró [‘blasfemó’] ${ }^{18}$ en la Meguilá. Tamién tú haź crujir a sus dientes y di a él: «Y todo esto no conviene ${ }^{\circ}$ a mí»: a mí y non a él; ${ }^{\circ}$ y si era ahí, era colgado.

לא En J894h un errado לו lo 'a él' lo que en V850 (h. 2b) es la negación lo 'no'; sin embargo es correcta la formulación en $\mathrm{J} 894 \mathrm{j}$.- Tal repetición de $a$ vos de J894j no aparece en V850 ni en J894h.- En V850 no se repite לי lí / a mí, como sí sucede en J894h/j.- En V859 sólo אלו ilu 'si' y no el ואלו veilu 'y si' de J894h/j.

9.- [Prenismo, ¿que él dićién?: «QQué esto?». Y dirás a él: «Con fortaleźa de poder mos sacó Yy de Ayifto, de caśa de siervos» (S872 h. 11a) ${ }^{37}$.]

תם מה הוא אומר מה זאת ואמרת אליו סעודת פורים הוא וכל ׳המתעסקים

בה זוכים ליהנות מסעודה של לויתן.

Tam, ¿ma hu omer?: «¿Ma źot?». Veamartá elav: «Se“udat Purim hu, vejol ${ }^{\circ}$ hamit'asequim bah ${ }^{\circ}$ źojim lihenot mise ‘udá šel Liviatán.

Pleniśmo, ¿qué él dićién?: «¿Qué esto?». Y dirás a él: «Se“udá de Purim es, y todo el que ${ }^{\circ}$ se entremete en ella ${ }^{\circ}$ es źojé ['merece'] de aprovecharse de se “udá de Liviatán ${ }^{38}$ ».

En V850 (h. 2b) y en J894h los dos participios המתעסקים hamit'asequim 'se ocupan' y זוכים zojim 'merecen' están en plural, pero en $\mathrm{J} 894 \mathrm{j}$ en singular: se entremete y źojé 'merece'.

10.- [Y el que no sabe por demandar tú enveza a él, que ansí diće el pasuc: «Y denunciarás a tu hijo en el día el este por dećir: "Por esto hiźo a mí en mi salir de Ayifto"».

¿Podía ser de precipio de meś?; deprendimiento para dićir: en el día el este. Si en el día el este, ¿podía ser de tenprano de día?; deprendimiento para dićir: por esto. Por esto non dije, salvo en hora que maŝá y lechuga puestos delantre de ti (S872 11b) ${ }^{39}$.]

${ }^{37}$ 'El necio, ¿qué dice?: «¿Qué es esto?».Y le dirás: «Con mano fuerte nos sacó el Señor de Egipto, de casa de esclavos» [Éx 13:14]'.

${ }^{38}$ Se refiere al Leviatán, animal mítico al que se considera el rey de los peces y cuya carne degustarán los justos con la llegada de los tiempos mesiánicos.

39 ' $Y$ al que no sabe preguntar ábrele (su mente), pues está dicho: «Y dirás a tu hijo en aquel día diciendo: "Por esto (que) me hizo el Señor en mi salida de Egipto"» [Éx 13:8]. // 
ושאינו יודע לשתות את פתח לו את הפה שנאמר הרחב פיך ואמלאהו ונאמר

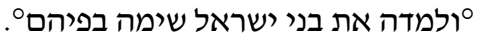

Vešeenó yodea' lištot at petah lo et hapé, šeneemar: «Harḥeb pija vaamal'ehu», veneemar: " ${ }^{\circ} V e l a m e d a h$ et bené Yisrael, simah befihem ${ }^{\circ}$.

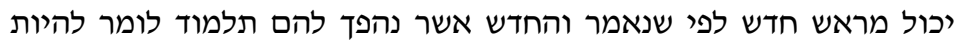

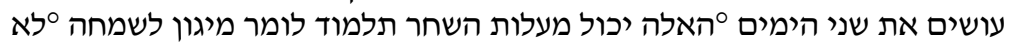
אמרתי אלא בשעה שהכוסות ׳מזים מזוגין לפניך.

¿Yajol meróš ḥodeš, lefí šeneemar: «Vehaḥodeš ašer nehefaj lahem»?: talmud lomar: «lihyot 'osim et šené hayamim ${ }^{\circ}$ haele». ¿Yajol me ‘alot hašáhar?: talmud lomar: «miyagón lesimháa `lo amarti, ela beša‘á šehakosot ${ }^{\circ}$ meźuguín lefaneja.

Y el que no sabe por beber tú abre a él a la boca, como diće el pasuc: «Anchea ['abre de par en par'] tu boca y la henchiré» [Sal 81:11], y fue dicho: «'Y anveźa ['enseña'] a hijos de Yisrael, ponla en sus bocas» [Deut 31:19].

¿Puedía ser de precipio de meś, siendo que diće el pasuc: «Y el meś que se trastornó a ellos» [Ester 9:22]?: deprendimiento para dećir ${ }^{40}$ : «Por ser haćientes a dos los días ${ }^{\circ}$ los estos» [Ester 9:27]. ¿Puedía ser del amanecer?: deprendi- ${ }^{9}$ miento para dećir: «de ansia a alegría» [Ester $9: 22]^{\circ}$ no dije, salvo en hora que los vaśos ${ }^{\circ}$ templados delantre de ti.

En V850 (h. 2b) el primer parágrafo aparece separado del siguiente, que comienza יכול Yajol, pero no en J894h/j ni en S872, en donde aparecen unidos.- Pero en V850 y en J894h ולמדה velamedah 'y enséñala', según el versículo citado de Deut 31:19.

En V850 החם hahem 'ellos' en lugar de האלה haele 'estos' de J894h/j, que es lo que también dice el versículo citado de Ester 9:27.- En V850 se repite לשמחה lesimhá 'a alegría' ante לא אמרתי lo amarti 'no he dicho', pero no en J894h/j; esta primera persona imita la fraseología de la argumentación rabínica en la que el hablante es el rabino que ha suscitado la cuestión.- J894j traduce correctamente por 'templados' lo que en V850

(Lo de narrar el éxodo de Egipto) ¿puede ser desde el principio del mes (de nisán)?; pero se dice en aquel día. ¿Acaso en aquel día puede (interpretarse) cuando aún es de día?; pero está dicho por esto. Por esto no he dicho, sino (que se refiere) a la hora que el pan ácimo y la lechuga están puestos ante ti'.

${ }^{40}$ Fórmula retórica de la argumentación rabínica que viene a poner objeciones a lo dicho anteriormente, aduciendo versículos bíblicos o pasajes talmúdicos. 
y en J894h es מזוגין meźuguín 'mezclados; servidos, escanciados', y tal jsp. templados no tiene aquí el significado que podría pensarse a primera vista de 'calentados'; recuérdese al respecto que el verbo latino tempero como transitivo tiene también el significado de 'mezclar' y así se ha usado en español medieval ${ }^{41}$.

11. - [De precipio sirvientes 'abodá źará eran muestros padres y agora mos allegó el Criador a su servicio, que ansí diće el pasuc: «Y dijo Yehošúa" a todo el pueblo: "Ansí diǰo Yy, Dio de Yisrael: En parte de el río estuvieron nuestros padres de siempre, Térah, padre de Abraham y padre de Naḥor, y sirvieron diośes otros"» (S872 h. 11b $)^{42}$.]

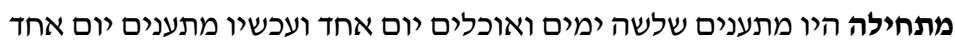

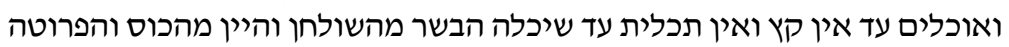

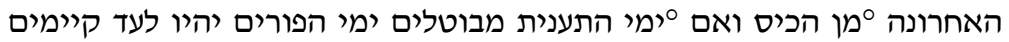

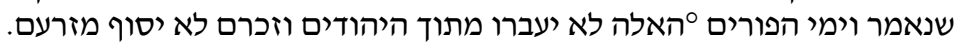

Miteḥilá hayú mit'anim šelošá yamim veojelim yom eḥad ve‘ajšav mit'anim yom eḥad veojelim 'ad en queŝ veén tajlit, 'ad šeyijlé haḅasar mehašulhán vehayayin mehakós vehaperutá haaḥaroná ºmin hakís. Veím `yemé hata'anit mebutalim, yemé haPurim yihyú la'ed cayamim, šeneemar: «Vimé haPurim ${ }^{\circ}$ haele lo ya 'aberú mitoj hayehudim veźijram lo yasuf miźar'am».

De precipio haćían ta 'anit ['ayunaban'] tres días y comían día uno y agora haćen ta 'anit día uno y comen hasta non fin y non cabo, hasta que se atema la carne de la meśa y el vino de el vaśo y la pará ['moneda'] prostera de ${ }^{\circ}$ la bolsa. Y si ${ }^{\circ}$ días del ta 'anit se baldan, días de Purim serán por siempre firmes, que ansí diće el pasuc: «Y días de el Purim ${ }^{\circ} \mathrm{los}$ estos no pasarán de entre los jidiós y sus membraciones ['recuerdo'] no se tirará ['apartará'] de su semen» [Ester 9:28].

En V850 (h. 2b) מהכיס mehakis frente al מן הכיס min hakís de J894h, con el mismo significado.- En V850 el texto es más amplio: מי התענית עemé hata 'anit vehaguim 'los días de ayuno y fiestas', fiestas que se

${ }^{41}$ Sobre la expresión paralela de vino cocho, que, por otra parte, al haber sido cocido, pierde las exigencias de las reglas alimentarias del kašerut judío, vid. Romero Yantares p. 237.

42 'Al principio nuestros padres eran idólatras, pero ahora nos acercó el Creador a su servicio, pues está dicho: «Y dijo Josué a todo el pueblo: "Así ha dicho el Señor, Dios de Israel: Al otro lado del río [Eúfrates] se asentaron vuestros padres desde antiguo: Térah, padre de Abraham y padre de Naḥor, y sirvieron a otros dioses» [Jos 24:2]'. 
omiten en J894h/j.-- En V850 no aparece האלה haele 'estos', que sí está en el versículo de Ester 9:28 y también en J894h/j.

12.- [Bendicho el guardán su fiućia a Yisrael, bendicho Él. Que el Santo, bendicho Él, contán a la fin por haćer lo que dijo a Abraham, muestro padre, entre los espartimientos, que ansí diće el pasuc: «Y dijo a Abraham: "Saber sabrás que pelegrino será tu semen en tiera que non a ellos, y servirloś-han y afriirán a ellos cuatrocientos años. Y también a la gente que servirán juźgán Yo, y después ansí sarlán con ganancia grande (S872 h. 12a) ${ }^{43}$.]

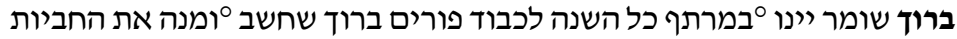

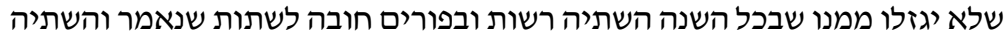
כדת שישתכר ויישן ׳בחלומן יחלו יראה שיש לו רכוש גדול.

Baruj šomer yenó obemartef kol hašaná lijbod Purim; baruj šeḥašab oumaná et hahabiyot šeló yigźelú mimenu. Šeḅejol hašaná hašetiyá rešut ubePurim hobá lištot, šeneemar: «Vehašetiyá kaḍat». Šeyištaker veyišán, ’baḥalomó yiré šeyéš lo rejúš gadol.

Bendicho guadrán su vino ${ }^{\circ}$ al magaćén todo el año por kebod ['honra de'] Purim; bendicho que ${ }^{\circ}$ contó las botas ${ }^{\mathbf{1 0}}$ que non roben de él. Que en todo el año el beber rešut ['está permitido'] y en Purim obligo por beber, que ansí diće el pasuc: «Y el beber como la ley» [Ester 1:8]. Que se enborache y que durma, ${ }^{\circ}$ en su esfueño y verá que hay a él ganancia grande.

En V850 (h. 2b) במרתף bemartef 'en un sótano', pero en J894j con artículo «al magaćén»; recordemos que J894h no está vocalizado.- En V850 tras maná 'calculó' se añade וספר vesafar 'enumeró, que no está en J894h/j; por su parte en J894j los dos verbos de su base han quedado reducidos a uno, contó.- En V850 precede a בחלומו bahalomó la conjunción - ו ve- 'y’ ubahalomó ‘y en su sueño', que no está en J894h/j.

${ }^{43}$ 'Bendito el que mantiene su confianza en Israel, bendito sea. Que el Santo, bendito sea, tuvo en cuenta (de antemano) el fin (de la esclavitud) para hacer lo que prometió a Abraham, nuestro padre, en el pacto entre los trozos (de las ofrendas) [Gén 15:9-10], como está dicho: «Y dijo a Abraham: "Saber sabrás que extranjera será tu prole en una tierra que no le pertenece, y los esclavizarán y los oprimirán durante cuatrocientos años. Pero también a la nación a la que servirán Yo los juzgaré, y tras ello saldrán con grandes riquezas"»". 
13.- [Ella que estuvo a muestros padres y hijos, que no uno tan sólamente estuvo sobre nos, salvo que en cada arnancio y arnancio estantes sobre nos por atemarmos y el Santo, bendicho Él, mos escapa de sus manos (S872 h. 12b) ${ }^{44}$.]

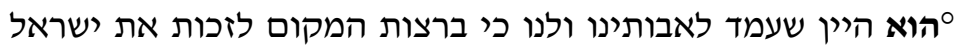

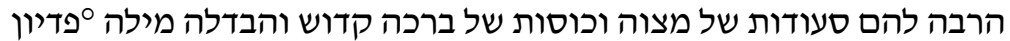

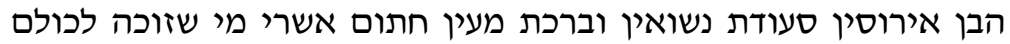

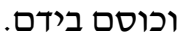

${ }^{\circ} H u$ hayayin še 'amad laabotenu velanu, ki, birŝot haMacom leźakot et Yisrael, hirbá lahem se 'udot šel miŝvá vekosot šel berajá: quiḍúš vehabdalá, milá, opidión habén, erusín, se ‘udat nesuín ubirkat «ma‘ayán ḥatum». ¡Ašré mi šeźojé lejulam vejosam beyadam!

'Él el vino que se aparó a ['se puso ante'] muestros padres y a nos, que, enveluntar ${ }^{45}$ el Criador por ser źojé ['hacer alcanzar méritos'] a Yisrael, munchiguó a ellos ['les aumentó'] se'udot ['banquetes'] de encomendanza y vaśos de bendición: quiḍúš ['bendición del vino'], habdalá ${ }^{46}$, cercución ['circuncisión'], ${ }^{\circ}$ regmición del hijo ${ }^{47}$, espośorio, caśamiento, ${ }^{\circ}$ bendición «fuente cerada» [Cant 4:12] ${ }^{48}$. ¡Bienaventurado quen es źojé a todos ellos ${ }^{49}$ y sus vaśos en sus manos!

En V850 (h. 3a) והוא Vehú 'Y él (es)', frente al הוא Hu 'Él (es)' de $\mathrm{J} 894 \mathrm{~h} / \mathrm{j}$, y algunas de sus frases van unidas mediante dicha conjunción ve'y'.- En V850 tras ופדיון הבן ufidión habén 'y rescate del niño' se añade בר מצוה bar miŝvá '(ceremonia de la) mayoría de edad', que no aparece en J894h/j.- Dado el estado constructo de ברכת ubirkat en V850 y J894h, la traducción correcta de J894j debería haber sido ‘bendición de', donde también se ha omitido la conjunción ilativa inicial - ו $u$ - 'y'.

${ }^{44}$ 'Esa (promesa) es la que sostuvo a nuestro padres y a nosotros, que no fue sólo uno el que se alzó contra nosotros, sino que en cada generación y generación se alzan contra nosotros para destruirnos, pero el Santo, bendito sea, nos salva de sus manos'.

${ }^{45}$ Probable error por enveluntán, es decir, queriendo.

${ }^{46} \mathrm{Hb}$. הבדלה (lit. 'separación, diferenciación'): ceremonia al término de sábados y días festivos para separar el día santo que acaba del profano que comienza.

${ }^{47}$ Hb. pidión haben 'rescate del niño', ceremonia que se practica al mes del nacimiento.

${ }^{48} \mathrm{La}$ expresión se refiere al desfloramiento de la mujer virgen.

${ }^{49}$ Es decir, quien merece (es źojé) celebrar todos esos acontecimientos que implican bendiciones sobre el vino. 
14.- [Sal y deprende qué bušcó Labán el aramí por haćer a Ya 'acob, muestro padre, que Par'ó no setenció salvo sobre los machos y Labán bušcó por arancar a lo todo, que ansí diće el pasuc: «Aramí quis̀o depedrer a mi padre, y decendió a Ayifto y moró ahí con varones pocos; y fue ahí por ĝente grande, fuerte y mucha» ${ }^{50}$. Y decendió a Ayifto forzado por dicho de el mandamiento. Y moró ahí mos enṿeźa que non decendió por afincarse, salvo por morar ahí, que ansí diće el pasuc: «Y dijeron a Par'ó: "Por morar en la tiera vinimos, que no pasto a las ovejas que a tus siervos, que peśgada la hambre en tiera de Kená'an. Y agora estén agora tus siervos en tiera de Gošen"». Con varones pocos, como ansí diće el pasuc: «Con setenta almas decendieron tus padres a Ayifto y agora te puśo Yy, tu Dio, como estrellas de los cielos a muchedumbre». Y fue ahí por gente grande mos enveźa que era Yisrael aseñalados ahí por ĝente grande. Y fuerte, como ansí diće el pasuc: «Y hijos de Yisrael frochiguaron y serpieron y muchiguáronse y enforteciéronse en lo muncho muncho y hinchose la tiera de ellos». Y mucho, como ansí diće el pasuc: «Milaria, como hermollo de el campo, te di y muchigüite y engrandecite y truj̄ite en afeites de afeites; pechos hueron conpuestos y tu cabello hermoeció, y tú desnudo y descubierto» (hs. 12b-14a) (.... $)^{51}$.]

${ }^{50}$ En S872 todas las frases que se inician con cursiva en nuestra edición constituyen párrafos diferentes; no así en V850 ni en los textos que edito.

51 'Sal y aprende qué quiso Labán, el arameo, hacer a Jacob, nuestro padre, que el Faraón no dictó sentencia salvo contra los varones [cfr. Éx 1:22], pero Labán quiso arrancarlos a todos, pues está dicho: «Un arameo quiso perder a mi padre, y descendió a Egipto y estableciose allí con poca gente, pero se convirtió en un pueblo grande, potente y numeroso» [Deut 26:5]. $Y$ descendió a Egipto obligado por la palabra (divina). Y estableciose allí nos enseña que no bajó para quedarse, sino para habitar allí (temporalmente), pues está dicho: «Y dijeron (los hermanos de José) al Faraón: "A alojarnos en el país hemos venido, pues no hay pasto para el ganado que tienen tus siervos, ya que es grave el hambre en la tierra de Canaán. Ahora bien, permite que tus siervos habiten en la tierra de Gošen» [Gén 47:4]. Con poca gente, como está dicho: «Con setenta personas bajaron tus padres a Egipto y ahora te ha hecho el Señor, tu Dios, como las estrellas de los cielos en muchedumbre» [Deut 10:22]. Y se convirtió en pueblo grande nos enseña que Israel se distinguieron allí como un pueblo numeroso. Y fuerte, como está dicho: «Y los hijos de Israel crecieron y se reprodujeron y aumentaron y se hicieron muy fuertes y se llenó la tierra de ellos» [Éx 1:7]. Y numeroso, como está dicho: «A millares, como la hierba del campo, te he puesto, y te hice crecer y te engrandecí y te hice cubrir de afeites; tus senos se afirmaron y tu vello brotó, pero estabas desnuda y descubierta» (...) $[E z$ 16:7]'. Aunque poco tiene que ver este texto con el paródico que edito, lo reproduzco para dejar constancia del método seguido: el midrásico de citar pasajes bíblicos e interpretarlos, que es el mismo que, parodiando, se usa aquí y en otros pasajes siguientes. A continuación se omiten varios de los parágrafos en los que en la Haǵadá tradicional se desglosa éste que se inicia « $\hat{\mathrm{S} e}$ ulmad», pero se añaden otros que luego señalo. 


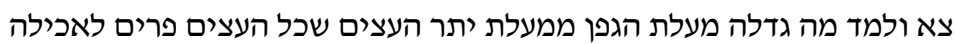

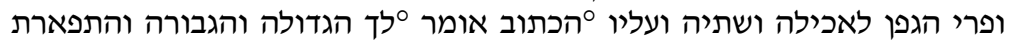

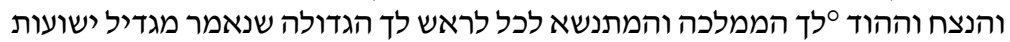

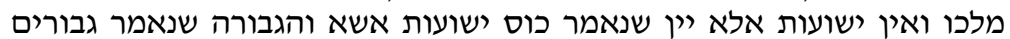

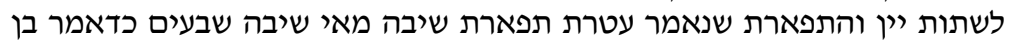

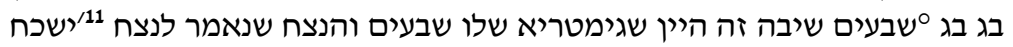

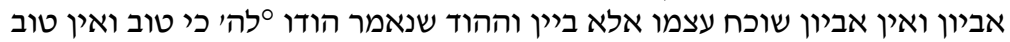

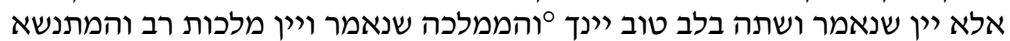

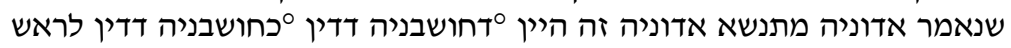

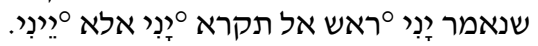

Ŝe ulmad ma gadelá ma'alat hag̉uefen mima'alat yeter ha'eŝim, šekol ha'eŝim piryam laajilá uferí hag̉uefen laajila ušetiyá, ve‘alav `haKatub omer: «'Lejá hag̉uedulá vehag̉ueburá vehatif’éret vehanéŝạ vehahod»; «'Lejá hamamlajá vehamitnasé lejol leróš». Lejá haġuedulá, šeneeamar: «Magḍil yešu'ot malkó», veén yešu 'ot ela yayin, šeneemar: «Kos yešu'ot esá». Vehag̉ueburá, šeneemar: «Guiḅorim lištot yayin». Vehatif'éret, šeneemar: «'Atéret tif'éret sebá», ¿may sebá?: šib'im, kideamar Ben Bag Bag: «'Šib im sebá źe hayayin, šeguimatriá šeló šib“im». Vehanéŝah, šeneemar: «Lanéŝah yišajah ebyón», veén ebyón šojeah 'aŝmó ela beyayin. Vehahod, šeneemar: «Hodú 'laH' ki tob», veén tob ela yayin, šeneemar: «Ušté beleb tob yeneja». ${ }^{\circ}$ Vehamamlajá, šeneemar: «Veyayin maljut rab». Vehamitnasé, šeneemar: «Adoniyá mitnasé»; Adoniyá źe hayayin, ${ }^{\circ}$ de-huušḅeneh de-den ${ }^{\circ}$ kehušḅeneh deden. Leróš, šeneemar: «Yaní ${ }^{\circ}$ roš»; al ticrá ${ }^{\circ}$ yaní ela ${ }^{\circ}$ yení.

Sal y deprende ['aprende'] cuanto se engrandeció el grano de la vid más de grano de resto de árboles, que todos los árboles sus fruto por comer y fruto de la vid por comer y beber, y sobre él ${ }^{\circ}$ diće el pasuc: ${ }^{\circ} \mathrm{A}$ ti la grandeźa y la baraganía y la hermośura y el vencimiento y la loor»

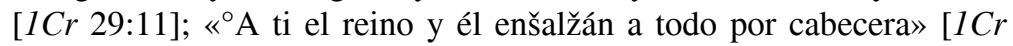
29:11 $]^{52}$. A ti la grandeźa, como ansí dice el pasuc: «Engrandeció salvaciones de su reino» [2Sam 22:51 y Sal 18:51], y non salvaciones salvo vino, como diće el pasuc: «Vaśo de salvaciones alzaré» [Sal 116:13]. Y la baraganía, como diće el pasuc: «Baraganes por beber vino» [Is 5:22]. Y la hermośura, como diće el pasuc: «Corona de hermośura caneźa» $[\mathrm{Pr}$

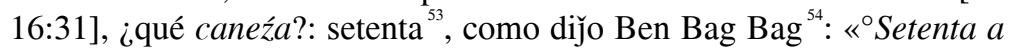

${ }^{52}$ En los pasajes bíblicos citados se está hablando de Dios.

${ }^{53}$ Es decir: «¿qué significa canicie?: setenta», que según se dice luego es la edad en que se tienen canas.

${ }^{54}$ Nombre inventado en el que hay ciertas resonancias fonéticas con el פת בג pat bag o ‘manjares' que de la mesa del rey se destinan a Daniel, según el pasaje de Daniel 1:5. 
la caneźa, esto el vino, que la cuenta suya setenta ${ }^{55} »$. Y el vencimiento, como diće el pasuc: «Por siempre será olvidado deśeośo» [Sal 9:19], y non deśeośo olvidán a sí miśmo salvo con vino. Y la loor, como diće el pasuc: «Load a ${ }^{\circ} \mathrm{H}^{\prime}$ que bueno» [Sal 106:1, etc.], y non bueno salvo vino, como diće el ${ }^{1 / 2}$ pasuc: «Y bebe con corazón bueno tu vino» $[E c l$ 9:7]. ${ }^{\circ} Y$ el reino, como dice el ${ }^{/ 12}$ pasuc: «Y vino de reino muncho» [Ester 1:7]. Y él enšalžado, como diće el pasuc: «Adoniyá enšalžán» [cfr. lReyes 1:5]; Adoniyá esto el vino, que la ${ }^{\circ}$ cuenta de éste como la ${ }^{\circ}$ cuenta de éste ${ }^{56}$. Por cabecera, como diće el pasuc: «Vedará ${ }^{\circ} \mathrm{mi}$ cabeza» [Sal 141:5]; no meldes ${ }^{\circ}$ vedará salvo mi vino.

En V850 (h. 3a) אמר הכתוב amar haKatub 'dijo la Escritura' frente a J894h הכתוב אומר haKatub omer 'la Escritura dice'; por su parte J894j sustituye Escritura por pasuc 'versículo'.- En el versículo citado de 1 Cr 29:11, tras los dos לך lejá 'a ti' figura el Tetragrámaton, que ha desaparecido de V850 y de J894h/j.- En V850 לן שבעים ben šib 'im, habiéndose omitido ben en $\mathrm{J} 894 \mathrm{~h} / \mathrm{j}$; podemos entender la frase 'el de setenta [años tiene] caneza'.- En la cita del versículo de Sal 106:1 aparece el Tetragramaton, sustituido en nuestros textos

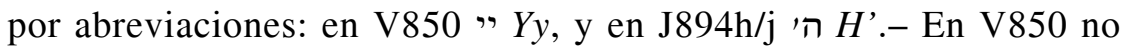
hay - וממלכה he- 'y' amamlajá 'el reino', que sí aparece en

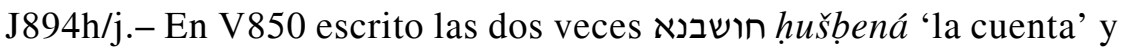
así también en J894j, mientras que en J894h es חושבניה hušḅeneh 'su cuenta'.- En V850 y J894h ראש roš 'cabeza' lo que en el versículo de Sal 141:5 citado es ראשי roši 'mi cabeza', bien traducido en J894j.יני En J894h están vocalizadas las palabras que forman el juego entre yaní ( $3^{\mathrm{a}}$ pr. msc. del futuro de la raíz hb. נוא n.v.') 'rehusará' y יני yení 'mi vino', juego que se pierde en $\mathrm{J} 894 \mathrm{j}$.

15. - [En la Hagadá tradicional sólo un parágrafo se inicia con Dabar aher que corresponde a núm. 17 infra, añadiéndose aquí este parágrafo y el siguiente, los cuales aluden a temas exclusivos del libro de Ester.]

\footnotetext{
${ }^{55}$ Es decir, que el valor numérico de las letras hebreas de la palabra yayin suman setenta.

${ }^{56}$ Es decir, el valor numérico de las letras del nombre hebreo de Adonías y el de la palabra hebrea yayin suman setenta. Recordemos, según se narra en 1Reyes 1 y ss., que Adonías, hijo de David, tuvo sus más y sus menos con su hermanastro Salomón, quien ordenó darle muerte.
} 


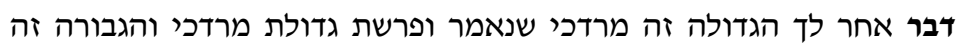

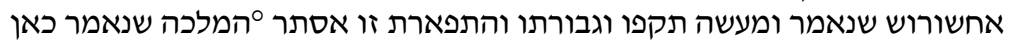

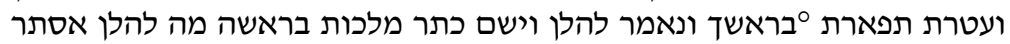

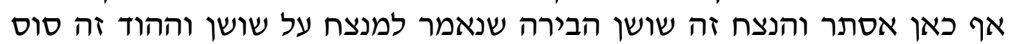

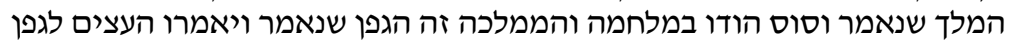

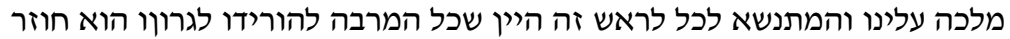

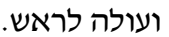

Dabar aḥer. Lejá hag̉uedulá źe Mordejay, šeneemar: «Ufarašat gedulat Mordejay». Vehagiueburá źe Aḥašveróš, šeneemar: «Uma'asé tocfó ugburató». Vehatif'éret źu Ester `hamalká, šeneemar kan: «Va‘atéret tif'éret 'berošej», veneemar lehalan: «Vayásem kéter maljut berošah»; ma lehalan Ester, af kan Ester. Vehanéŝah źe Šušán habirá, šeneemar: «Lamenaŝéah 'al Šušán». Vehahod źe sus hamélej, šeneemar: «Vesús hodó bamilḥamá». Vehamamlajá źe hag̉uefen, šeneemar: «Vayomerú ha "eŝim lag̉uefen: "Moljá 'alenu”». Vehamitnasé lejol leróš źe hayayin, šekol hamarbé lehoridó ligronó hu ḥoźer ve 'olé leróš.

Cośa otra. A ti la grandeźa éste Mordejay, como diće el pasuc: «Y declaramiento de grandeźa de Mordejay» [Ester 10:2]. Y la baraganía éste Aḥašveróš, como diće el pasuc: «Y hecha de su fortaleźa y su baraganía» [cfr. Ester 10:2]. Y la hermośura ésta ${ }^{\circ}$ Ester, que fue dicho aquí: «Y corona de hermośura ${ }^{\circ}$ en tu cabeza» [ $E z$ 16:12], y fue dicho ahí: «Y puśo corona de reino en su cabeza» [Ester 2:17]; como ahí Ester, también aquí Ester. Y el vencimiento éste Šušán habirá ['la fortaleza'], como ${ }^{/ 13}$ diće el pasuc: «A el menaŝéạ ${ }^{57}$ sobre Šušán ${ }^{58}$ » [Sal 60:1]. Y la loor éste caballo del rey, como diće el pasuc: «Y caballo de su loor en la pelea» [cfr. Zac 10:3]. Y el reino esto la vid, como diće el pasuc: «Y dijeron los árboles a la vid: "Enreina sobre mośotros"» [cfr. Jue 9:12]. Y él enšalžán a todo por cabecera esto el vino, que todo el que muchigua por decenderlo a su garón ['garganta'] él torna y sube por cabecera.

En V850 (h. 3a) este parágrafo está unido al anterior; sigo la partición de J894h/j.- En V850 no figura המלכה hamalká 'la reina' de J894h, que tampoco aparece en J894j.- En J894h/j es más amplia la cita de Ez 16:12, añadiendo a V850 בראשך berošej 'en tu cabeza'.

${ }^{57}$ Juego de palabras entre menaŝéạ, palabra habitual al inicio de varios versículos de Salmos, que suele interpretarse como 'el director del coro', y que aquí se pone en contacto con la raíz hb. נצח n.s.h 'vencer'.

${ }^{58}$ Juego de palabras entre el nombre de la capital de Persia y el sustantivo hb. šušán 'lirio', que es el que figura en el versículo de Salmos. 
16.- [Como he indicado supra, este parágrafo tampoco figura en la Haǵadá tradicional.]

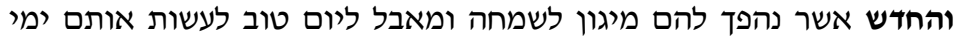

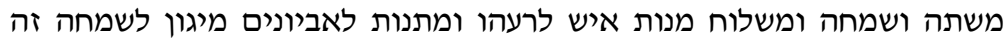

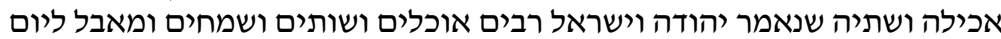

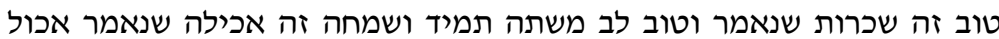

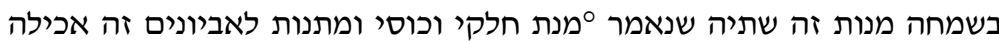
שנאמר ואביוניה אשביע לחם.

«Vehaḥodeš ašer nehepaj lahem miyagón lesimhá umeébel leyom tob la'asot otam yemé mišté vesimhá umišlóạ̣ manot iš lere 'ehu umatanot laebyonim». Miyagón lesimhá źe ajilá ušetiyá, šeneemar: «Yehudá veYisrael raḅim ojelim vešotim usmehim». Umeébel leyom tob źe šijrut, šeneemar: «Vetob leb mišté tamid». Vesimhá źe ajilá, šeneemar: «Ejol besimhá». Manot źe šetiyá, šeneemar: «"Menat helquí vejosí». Umatanot laebyonim źe ajilá, šeneemar: «Veebyonéah asbịía láḥ̣em».

«Y el meś que se trastornó a ellos de ansia a alegría y de limuño a día bueno por haćer a ellos días de conṿite y alegría y enṿiar preśentes cada uno a su conpañero y dádivas a los deśeośos» [Ester 9:22]. De ansia a alegría esto comer y beber, como diće el pasuc: «Yehudá ['Judá'] y Yisrael munchos comientes y bebientes y alegrantes» [cfr. 1Reyes 4:20]. $Y$ de limuño a día bueno esto ${ }^{/ 14}$ boracheź, como diće el pasuc: «Y bueno de corazón conviite de contino» $[\operatorname{Pr} 15: 15]$. Y alegría esto comer, como diće el pasuc: «Come con alegría» [Ecl 9:7]. Preśentes esto beber, como diće el pasuc: ${ }^{\circ} \mathrm{H}^{\prime}$ dádiva de mi parte y mi vaśo» [Sal 16:5]. Y dádivas a los deśeośos esto comer, como diće el pasuc: «Y sus deśeośos hartaré pan» [cfr. Sal 132:15].

דבר En J894h este parágrafo aparece unido al siguiente que comienza אחר Dabar aher 'Otro asunto'; he preferido la partición de V850, que además coincide con la de J894j.- En Sal 16:5 מנת menat 'dádiva de' va precedido del Tetragrámaton, que en V850 (h. 3b) se sustituye por " Yy y en J894j por ה', abreviación que no aparece en J894h.

17.- [Uferúš otro. Con poder huerte, dos; y con brazo tendido, dos; y con temoridad grande, dos; y con señales, dos; y con maravillas, dos (S872 h. 16a) ${ }^{59}$.]

59 ' $\mathrm{Y}$ otra explicación. Con mano fuerte (se refiere a) dos (plagas); y con brazo extendido, (a otras) dos; y con temor grande, (a otras) dos; y con señales, (a otras) dos; $y$ con maravillas, (a otras) dos'. 
דבר אחר מיגון לשמחה שתים ומאבל ליום טוב שתים ׳ומשתה ושמחה שתים •ומתנות לאביונים שתים.

Dabar aher. Miyagón lesimhá, štáyim; umeébel leyom tob, štáyim; `umišté vesimhá, štáyim; ${ }^{\circ}$ umatanot laebyonim, štáyim.

Cośa otra. De ansia a alegría, dos; y de limuño a día bueno, dos; ${ }^{\circ}$ convite y alegría, dos; ${ }^{\circ}$ enviar preśentes, dos; y dádivas a deśeośos, dos [cfr. Ester 9:22].

En V850 (h. 3b) este parágrafo aparece unido al siguiente; he preferido la partición de J894h/j.- En V850 no hay - ושתה ve- 'y' ante mišté 'convite' ni tampoco en J894j, pero sí en J894h.- En V850 el texto es más largo, precediendo a J894h ומתנות לאביונים umatanot laebyonim 'y regalos a los pobres' el esperado ומשלוח מנות שתים לאיונים umišlóah manot štáyim 'y envío de regalos, dos', del versículo de Ester citado, palabras que también aparecen en $\mathrm{J} 894 \mathrm{j}$.

18.- [Estas dieź firidas que trujo el Santo, bendicho Él, sobre los aicianos en Ayifto, y estas ellas: sangre, ranas, piojos, mistura, mortaldad, sarna, pidrisco, langosta, escuridad, firida de mayores (S872 h. 16b) ${ }^{60}$.] אלו עשרת בני המן שנתלו על העץ בשושן ואלו הן פרשנדתא דלפון אספתא

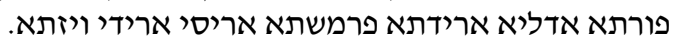

Elu 'aséret bené Hamán šenitelú 'al ha 'éŝ beŠušán, veelu hen: Paršandata, Dalfón, Aspata, Porata, Adaliá, Aridata, Parmašta, Arisay, Ariday, Vaiźata.

Estos diez hijos de Hamán que se encolgaron ${ }^{61}$ sobre la forca en Šušán, y estos ellos. Paršandata, Dalfón, Aspata, Porata, Adaliá, Aridata, Parmašta, Arisay, Ariday, Vaiźata [cfr. Ester 9:7-10].

19.- [Riḅí Yehudá era dan en ellos señales: desia”j, ‘adá”̌s, be’aha” $b$ (S872 h. 16b) ${ }^{62}$.]

$$
\text { רבי סאכלן היה נותן בהם סימנים פרדלאספור אדלאריפר ארי אריוי. }
$$

${ }^{60}$ 'Estas son las diez plagas que hizo venir el Santo, bendito sea, sobre los egipcios en Egipto, y son éstas: sangre [dam], ranas [ $\hat{\text { sefardea }}$ ], piojos [kinim], animales feroces ['erub], peste [déber], sarna [šehín], pedrisco [barad], langosta [arbé], tinieblas [hóšej], muerte de los primogénitos [bejorot]'.

${ }^{61}$ Es decir, que fueron colgados.

62 'Rabí Yehudá hacía con ellas (con las iniciales de los nombres de las plagas) un

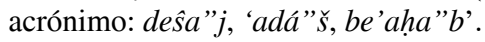


Raḅi ${ }^{\circ}$ Ajlán hayá notén bahem simanim: pardal'aspor 'adal'ari'afar 'arí 'arivay.

Rabíi 'Źamrán era sam ['ponía'] en ellos señales: pardal'aspor 'adal'ari'afar 'arí 'arivay.

En V850 (h. 3b), como también en J894j, el nombre del rabino no es el זמרן Ajlán 'Comilón' de J894h, sinón 'Cantor'.

20.- [Riḅí Yose el galilí dićién: «¿De adónde tú dićién que hueron firidos los aicianos en Ayifto dieź firidas y sobre la mar ḥueron firidos cincuenta firidas? ${ }^{63}$. En Ayifto, ¿qué él dićién?: "Y dijeron los megos a Par'ó: «Maravilla de el Dio ella»”. Y sobre la mar, ¿qué él dićién?: "Y vido Yisrael a la maravilla la grande que hiźo Yy en Ayifto (...)". ¿Cuántos hueron firidos con el dedo?: dieź firidos. Di de agora: en Ayifto hueron firidos dieź firidas y sobre la mar hueron firidos cincuenta firidas» (S872 hs. 16b-17a) ${ }^{64}$.]

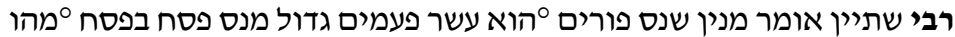

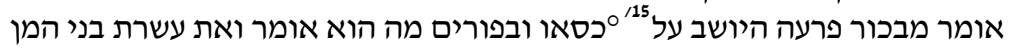

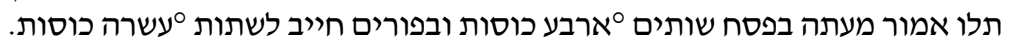

Rabí Šatyán omer: «¿Minayin šenés Purim `hu 'éser pe‘amim gadol minés Pésaḥ?: bePésah, ¿ ${ }^{\circ}$ mahú omer?: "Miḅejor Par'ó hayošeb 'al "kisó”; ubePurim, ¿ma hu omer?: "Veet 'aséret bené Hamán talú”. Emor me 'atá: bePésah šotim ${ }^{\circ}$ arḅa ' kosot ubePurim hạayab lištot ${ }^{\circ}$ 'asará kosot».

Rabí Šatyán dićién: «¿De adónde que nes ['el milagro de’] Purim ${ }^{\circ}$ era diez većes grande más ${ }^{65}$ de nes de Pésạ̣?: en Pésaḥ, $\iota^{\circ}$ qué él dićién?: “De mayor ['primogénito'] de Par'ó ['el Faraón'] el están sobre "sía" [Éx 11:5]; y en Purim, ¿qué él dićién?: "Y a diez hijos de Hamán encolgaron" [Ester 9:14]. Di de agora: en Pésah beben ${ }^{\circ}$ cuatro vaśos y en Purim obligado por beber ${ }^{\circ}$ diez vaśos».

${ }^{63}$ En S872 las contestaciones a las preguntas que siguen constituyen parágrafos separados.

${ }^{64}$ 'Rabí Yose el galileo dice: «¿De dónde sacas lo que dices de que fueron heridos los egipcios en Egipto con diez plagas y en el mar fueron heridos con cincuenta plagas? De Egipto, ¿qué se dice?: "Y dijeron los magos al Faraón: «Es un milagro [de un dedo] de Dios»" [Éx 8:15]. Y del mar, ¿qué se dice?: "Y vio Israel el gran milagro [de la mano poderosa] que hizo el Señor en Egipto (...)" [Éx 14:31]. ¿Cuántos fueron heridos con un dedo?: diez. Di desde ahora: (si) en Egipto fueron heridos con diez plagas, en el mar lo fueron con cincuenta plagas»'.

${ }^{65}$ Es decir, diez veces mayor. 
En V850 (h. 3b) היה hayá 'fue' en pasado en lugar del presente de J894h הוא hu 'él (es)', y a eso mismo parece responder el era de J894j.En V850 escrito מה חהו mahú de J894h, con el mismo significado de ‘¿qué (es)?'.- Responde a la formulación de Éx 11:5 la forma de J894h כסאו kisó 'su trono', lo que en V850 es כסע ' y así también en J894j.- En V850 כרבע פעמים arba 'á pe 'amim 'cuatro veces' y en J894h/j ארבע כוסות arba' kosot 'cuatro vasos'.- En V850 עשרה arḅa 'im pe ‘amim 'cuarenta veces', pero en J894h/j כרבעים פעמים כוסות 'asará kosot 'diez vasos'.

21.- [Ribíi Eli ‘éźer dićién: «¿De adónde tenemos que en cada firida y firida que trujo el Santo, bendicho Él, sobre los aicianos en Ayifto hue de cuatro firidas? Que ansí diće el pasuc: "Enṿiaré en ellos erecimiento de su fulor: saña y ira y angustia, enṿiamiento de mensajeros malos": saña, una; y ira, dos; y angustia, tres; enviamiento de mensajeros malos, cuatro. Di de agora: en Ayifto hueron firidos cuarenta firidas y sobre la mar hueron firidos doćientas firidas» (S872 hs. 17a-b) ${ }^{66}$.]

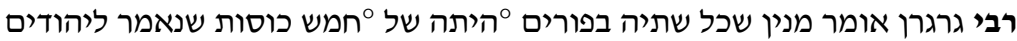

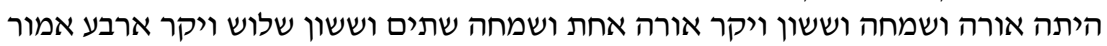
מעתה בפסח שותים ארבע כוסות וברות ובפורים שותים מאה וששים כות כוסות.

Rabịi Garguerán omer: «¿Minayin šekol šetiyá bePurim `hayetá šel `ḥaméš kosot? Šeneemar: "Layehudim hayetá orá vesimhá vesasón vicar”: orá, ahạt; vesimhá, štáyim; vesasón, šalóš; vicar, arḅa‘. Emor me ‘atá: bePésah šotim arḅa' kosot ubePurim šotim mea vešišim kosot».

Raḅí Garguerán dićién: «¿De adónde que cada bebida en Purim ${ }^{\circ} \mathrm{es}$ de cuatro vaśos? Como diće el pasuc: "A los jidiós fue luź y alegría y goźo y honra" [Ester 8:16]: luź, una; y alegría, dos; y goźo, tres; y hon$r a$, cuatro. Di de agora: en Pésạ̣ beben ${ }^{\circ}$ cuatro vaśos y en Purim beben cien y sesenta vaśos».

היתה En V850 (h. 3b) היא hi 'es (ella)', como en J894j, frente al hayetá 'fue (ella)' de J894h, respondiendo el femenino al sujeto שתיה šetiyá 'bebida'.- En J894h חמש haméš 'cinco', evidente error ya que las

${ }^{66}$ 'Rabí Eli ‘éźer dice: «¿De dónde (sale) que cada plaga y plaga que hizo venir el Santo, bendito sea, sobre los egipcios en Egipto está compuesta de cuatro plagas? De que dice el versículo: "Enviará contra ellos el furor de su cólera: saña e ira y angustia, [y] expedición de ángeles malos" [Sal 78:49]: saña es una; ira, dos; angustia, tres; [y] expedición de ángeles malos, cuatro. Di desde ahora: en Egipto fueron heridos con cuarenta plagas y en el mar lo fueron con doscientas plagas»'. 
causas que luego se argumentan son cuatro; en V850 ארבע arba' 'cuatro', como también en J894j.

22.- [Riḅí 'Aquibá dićién: «¿De adónde tenemos que en cada firida y firida que trujo el Santo, bindicho Él, sobre los aicianos en Ayifto era de cinco firidas? Que ansí diće el pasuc: "Enṿiaré en ellos erecimiento de su folor, saña, ira y angustia, enṿiamiento de mensajeros malos": erecimiento de su folor, una; saña, dos; ira, tres; angustia, cuatro; enyiamiento de mensajeros malos, cinco. Di de agora: en Ayifto hueron firidos cincuenta firidas y sobre la mar hueron firidos doćientas y cincuenta firidas» (S872 h. 17b) ${ }^{67}$.]

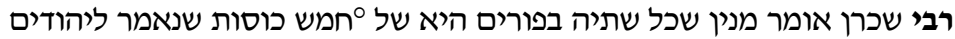

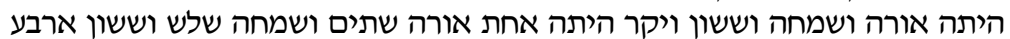

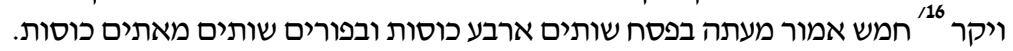

Raḅí Šajrán omer: «¿Minayin šekol šetiyá bePurim hi šel `haméš kosot? Šeneemar: "Layehudim hayetá orá vesimḥá vesasón vicar": hayetá, aḥat; orá, štáyim; vesimhá, šalóš; vesasón, arḅa‘; vicar, ḥaméš. Emor me 'atá: bePésah šotim arḅa' kosot ubePurim šotim maatayim kosot».

Raḅí Šajrán dićién: «¿De adónde que cada bebida en Purim es de cinco vaśos? Como diće el pasuc: "A los jidiós fue luź y alegría y goźo y honra" [Ester 8:16]: fue, una; luź, dos; y alegría, tres; y goźo, cuatro; y honra cinco. Di de agora: en Pésah beben cuatro vaśos y en Purim beben doćientos vaśos».

En V850 (h. 4a) חמשה hamišá 'cinco', escrito en J894h חמש haméš.

23.- [Cuantos grados buenos a el Criador sobre nos (S872 h. 17b) ${ }^{68}$.

Si mos sacara de Ayifto y no hićiera en ellos justicias, aḅastara a nos.

${ }^{67}$ 'Rabí 'Aquibá dice: «¿De dónde (sale) que cada plaga y plaga que hizo venir el Santo, bendito sea, sobre los egipcios en Egipto estaba compuesta de cinco plagas? De que está dicho [Sal 78:49]: "Enviará contra ellos: el furor de su cólera, saña e ira y angustia, (y) expedición de ángeles malos": el furor de su cólera, es una; saña, dos; ira, tres; angustia, cuatro; (y) expedición de ángeles malos, cinco. Di desde ahora: en Egipto fueron heridos con cincuenta plagas y en el mar lo fueron con doscientas cincuenta plagas»'.

${ }_{68}^{6}$ 'Cuántos buenos beneficios hizo el Creador con nosotros'. Sobre los acontecimientos a los que a continuación se alude cfr. el libro de Éxodo. En J894h/j el texto de la letanía que sigue va en líneas seguidas; en S872 el texto hebreo va separado por frases y el judeoespañol (hs. 17b-18a), como en el caso anterior, en líneas seguidas; y en V850 también se separan las frases. En mi presentación he optado por esta última partición. 
Si hićiera en ellos justicias y no hićiera en sus diośes, aḅastara a nos.

Si hićiera en sus diośes y no matara a sus mayores, aḅastara a nos.

Si matara sus mayores y no diera a nos a sus haćiendas, aḅastara a nos.

Si diera a nos sus haćiendas y no raśgara a nos a la mar, aḅastara a nos.

Si raśgara a nos a la mar y no mos hićiera pasar entre él por lo seco, aḅastara a nos.

Si mos hićiera pasar entre él por lo seco y no afincara muestros angustiadores entre él, aḅastara a nos.

Si afincara muestros angustiadores entre él y no aḅasteciera muestro menester en el diśierto cuarenta años, aḅastara a nos.

Si aḅasteciera muestro menester en el diśierto cuarenta años y no mos hićiera comer a la magna, aḅastara a nos.

Si mos hićiera comer a la magna y no diera a nos a el šaḅat, aḅastara a nos.

Si diera a nos a el šaḅat y no mos allegara delantre monte de Sinay, aḅastara a nos.

Si mos allegara delantre monte de Sinay y no diera a nos a la Ley, aḅastara a nos.

Si diera a nos a la Ley y no mos hićiera entrar a tiera de Yisrael, abastara a nos.

Si mos hićiera entrar a tiera de Yisrael y no fraguara a nos caśa del Santuvario, abastara a nos ${ }^{69}$.]

${ }^{69}$ 'Si nos hubiera sacado de Egipto y no los hubiera juzgado, nos bastaba. // Si los hubiera juzgado y no lo hubiera hecho con sus dioses, nos bastaba. // Si lo hubiera hecho con sus dioses y no hubiera dado muerte a sus primogénitos, nos bastaba. // Si hubiera dado muerte a sus primogénitos y no nos hubiera dado sus bienes, nos bastaba. // Si nos hubiera dado sus bienes y no nos hubiera rasgado el mar, nos bastaba. // Si nos hubiera rasgado el mar y no nos hubiera hecho pasar por medio de él en seco, nos bastaba. // Si nos hubiera hecho pasar por medio de él en seco y no hubiera ahogado a nuestros opresores dentro de él, nos bastaba. // Si hubiera ahogado a nuestros opresores dentro de él y no hubiera abastecido nuestras necesidades en el desierto durante cuarenta años, nos bastaba. // Si hubiera abastecido nuestras necesidades en el desierto durante cuarenta años y no nos hubiera hecho comer el maná, nos bastaba. // Si nos hubiera hecho comer el maná y no nos hubiera dado el sábado, nos bastaba. // Si nos hubiera dado el sábado y no nos hubiera acercado ante el monte Sinaí, nos bastaba. // Si nos hubiera acercado ante el monte Sinaí y no nos hubiera dado la Ley, nos bastaba. // Si nos hubiera dado la Ley y no nos hubiera hecho entrar en la tierra de Israel, nos bastaba. // Si nos hubiera hecho entrar en la tierra de Israel y no nos hubiera construido el Templo, nos bastaba'. 
כמה מעלות טובות למקום עלינו: אילו נהרגה ושתי ולא מלכה אסתר תחתיה דיינו. אילו מלכה אסתר ולא קראה את המן אל המשתה דיינו. אילו קראה אסתר את המן ולא נדדה שנת המלך דיינו. אילו נדדה שנת המלך ולא בא המן אל החצר דיאת ולינו. אילו בא המן אל החצר ולא ׳הרכיב את מרדכי על הסוס דיינו. אילו הרכיב את מרדכי ולא נפל על המטה דיינו. אילו נפל על המטה ולא דיבר חרבונה דיינו. אילו דיבר חרבונה ולא נתלו בני המן עם אביהם דיינו. אילו נתלו המן ובניו ולא ניתן רכושם למרדכי דיינו. אילו ניתן רכושם למרדכי ולא נעשה נקמה בשונאים דים דיינונו. אילו נעשה נקמה בשונאים ולא נקבעו ימי פורים דיינו. אילו נקבעו ימי פורים ולא נצטוינו לעשות משתה ושמחה דיינו.

Kama ma'alot tobot laMacom 'alenu: // Ilu nehergá Vaští veló maljá Ester taḥtéah, dayenu. // Ilu maljá Ester veló car’á et Hamán el hamišté, dayenu. // Ilu car’á Ester et Hamán veló nadedá šenat hemélej, dayenu. // Ilu nadedá šenat hamélej veló ba Hamán el hahaŝer, dayenu. // Ilu ba Hamán el hahasâer veló 'hirkib et Mordejay 'al hasús, dayenu. // Ilu hirkib et Mordejay veló nafal 'al hamitá, dayenu. // Ilu nafal 'al hamitá veló diḅer Harboná, dayenu. // Ilu diḅer Harboná veló nitelú bené Hamán 'im abihem, dayenu. // Ilu nitelú Hamán ubanav veló nitán rejušam leMordejay, dayenu. // Ilu nitán rejušam leMordejay veló na'asá necamá beson’im, dayenu. // Ilu na'asá necamá beson’im veló nicbe ‘ú yemé Purim, dayenu. // Ilu nicbe 'ú yemé Purim veló niŝtavinu la'asot mišté vesimhá, dayenu.

Cuantos grados ['grandezas'] buenos a el Criador sobre nos:

Si se mataba Vaští ${ }^{70}$ y no enreinaba Ester en su lugar [cfr. Ester 2], mos aḅastaba.

Si se enreinaba Ester ${ }^{/ 17}$ y no llamaba a Hamán a el conviite [cfr. Ester 5:4 y 7-8], mos aḅastaba.

Si llamaba Ester a Hamán y no se eśmovía ['alteraba’] esfueño del rey [Ester 6], mos aḅastaba.

Si se eśmovía esfueño del rey y no venía Hamán al cortijo [Ester 6:4 y ss.], mos aḅastaba.

${ }^{70}$ En Ester 1:16 y ss. no se habla directamente de la muerte de Vašti, asunto que queda implícito en el consejo de Memuján. 
Si venía Hamán al cortijo y no ${ }^{\circ}$ enbineyaba ['montaba'] Mordejay sobre el caballo [Ester 6:11], mos aḅastaba.

Si enbineaba a Mordejay y no caía sobre la cama [Ester 7:8], mos abastaba.

Si caía sobre la cama y no hablaba Harboná [Ester 7:9], mos aḅastaba.

Si hablaba Harboná y no se encolgaban hijos de Hamán con sus padre [Ester 9:25], mos aḅastaba.

Si se encolgaban Hamán y sus hijos y no era dada sus ganancias a Mordejay [Ester 8:7], mos aḅastaba.

Si era dada sus ganancias a Mordejay y no se haćía venganza en los enemigos [Ester 9:1 y ss.], mos aḅastaba.

Si se haćía venganza en los enemigos y no se asetiguaban ['instituían'] días de Purim [Ester 9:20 y ss.], mos aḅastaba.

Si se asetiguaban días de Purim y no mos encomendábamos por haćer conviite y alegría [Ester 9:22 y 27 y ss.], mos aḅastaba.

La omisión de la preposición $a$ hace que en J894j el sujeto de la acción sea Mardoqueo, traduciendo mal lo que en V850 y J894h es un verbo causativo הרכיב hirkib 'hizo cabalgar a'; sin embargo, en la frase siguiente sí encontramos la esperada proposición «Si enbineaba a Mordejay» y aún mejor se traduce el verbo causativo en núm. 24 infra donde J894j dice hizoo enbineyar a.

24.- [Sobre una cuanta más y cuanta más buena doḅlada y redoḅlada a el Criador sobre nos: mos sacó de Ayifto; hiźo en ellos justicias; hiźo en sus diośes; mató sus mayores; dio a nos a sus haćiendas; raśgó a nos a la mar; mos hiźo pasar entre él por lo seco; afincó muestros angustiadores entre él; hiźo aḅastecer muestro menester en el diśierto cuarenta años; mos hiźo comer a la magna; dio a nos a el šaḅat; mos hiźo allegar delantre monte de Sinay; dio a nos a la Ley; mos hizó entrar a la tiera de Yisrael; y fraguó a nos Caśa de la Escuǵida por perdonar sobre todos muestros dilitos (S872 hs. 19a-b) ${ }^{71}$.]

${ }^{71}$ 'Con cuanta más razón doblada y redoblada (es la alabanza) que le debemos al Creador: nos sacó de Egipto; los condenó; condenó a sus dioses; mató a sus primogénitos; nos dio sus bienes; nos rasgó el mar; nos hizo pasar por medio de él en seco; ahogó a nuestros enemigos dentro de él; abasteció nuestras necesidades en el desierto durante cuarenta años; nos hizo comer el maná; nos dio el sábado; nos acercó ante el monte Sinaí; nos dio la Ley, nos hizo entrar en la tierra de Israel; y nos construyó la Casa de la Elección (el Templo) para expiar 


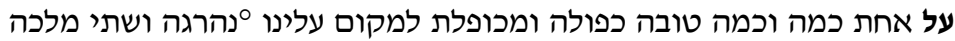

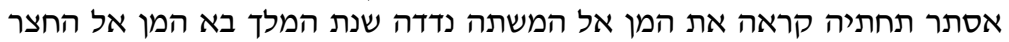

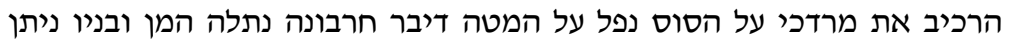

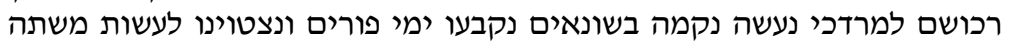

ושמחה בכל מושבותינו.

'Al aḥat kamá vejamá tobá kefulá umejupélet laMacom ‘alenu: ${ }^{\circ}$ nehergá Vaští; maljá Ester taḥtéah; car’á et Hamán el hamišté; nadedá šenat hamélej; ba Hamán el haḥaŝer; hirkib et Mordejay 'al hasús; nafal 'al hamitá; diḅer Harboná; nitlé Hamán ubanav; nitán rejušam leMordajay; na'asé necamá beson'im; nicbe ‘ú yemé Purim; veniŝtavinu la'asot mišté vesimhá bejol mošabotenu.

${ }^{/ 18}$ Sobre una cuanta más y cuanta más ${ }^{72}$ buena doḅlada y redoḅlada a el Criador sobre nos: ${ }^{\circ}$ fue matada Vaští; enreinó Ester en su lugar; llamó a Hamán a el conviite; se eśmovió esfueño del rey; vino Hamán al cortijo; hiźo enbineyar a Mordejay sobre el caballo; cayó sobre la cama; habló Ḥarboná; se encolgó Hamán y sus hijos; fue dada sus ganancias a Mordejay; se hiźo venganza en los enemigos; se asetiguaron días de Purim; y mos encomendamos por haćer conỵite y alegría en todas muestras moradas.

En V850 (h. 4a) שנהרגה šenehergá 'que fue matada', ש- še- 'que' que no aparece en J894h/j.- En V850 todas las frases que siguen van precedidas de la conjunción - וע ve- 'y', conjunción, que salvo en la última frase, no aparece en $\mathrm{J} 894 \mathrm{~h} / \mathrm{j}$.

25.- [Rabán Gamliel era dićién: «Todo quien que no diće tres cośas estas en Pésaḥ no sale abondo de su obligo, y éstas ellas: pésaḥ, maŝá y lechuga» (S872 h. 19b) ${ }^{73}$.]

רבן צחקיאל היה אומר כל ׳מי שלא עשה שלשה דברים ׳אלו בפורים לא יצא

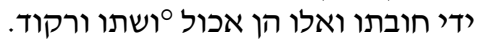

Raḅán Ŝahaquiel hayá omer: «Kol ํmi šeló ‘asá šelošá debarim elu bePurim lo yeŝé yedé ḥobató, veelu hen: ajol, `vešató veracod».

todos nuestros pecados'. La traducción literal de hb. בית הבחירה Bet haBehirá 'Casa de la Elección' para referirse al Templo la recoge SchWARZWALD (p. 323).

${ }^{72}$ Formulación del argumento a fortiori: «con cuanta más razón».

73 'Rabán Gamaliel decía: «Todo el que no menciona estas tres cosas en Pascua no cumple con su obligación, y son éstas: cordero pascual, pán ácimo y lechuga (= hierbas amargas)»'. La forma jsp. abondo para traducir hb. יצא ידי yesé yedé la recoge SCHWARZWALD (p. 288). 
Raḅán Ŝhạaquiel ${ }^{74}$ ['Burlón'] era dićién: «Todo ${ }^{\circ}$ el que no hiźo ${ }^{\circ}$ tres cośas en Purim no sale de su obligo, y estas ellas: comer, beber y bailar».

En V850 (hs. 4a-b) este párrafo aparece unido a los dos siguientes; sigo la partición de J894h/j.- En V850 (h. 4a) no hay mi 'quien', que sí aparece en J894h/j.- En V850 no está el אלו elu 'estas' de J894h, que tampoco aparece en J894j.- En V850 no hay conjunción - - ve- 'y' ante שתה šató 'beber', la cual tampoco aparece en J894j.

26.- [Corbán pésạ̣ (...) ¿por cavśa de qué? Por cavśa que saltó el Criador sobre caśas de muestros padres en Ayifto, que ansí diće el pasuc: «Y diredeš sangrificio de Pascua él a Yy (...) (S872 19b) ${ }^{75}$.] אכול כמו שנאמר לך אכול בשמחה לחמך ומנין שלחם הוא סעודה שניח שנאמר

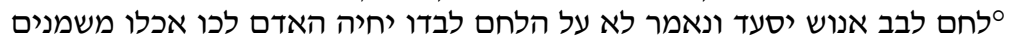

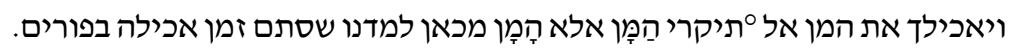

Ajol, kemó šeneemar: «Lej ejol besimhá laḥmejá». ¿Umináyim šeléḥem hu se "udá? Šeneemar: «'Léḥem lebab enóš yis ‘ad», veneemar: «Lo 'al haléḥem lebadó yiḥyé haadam»; «lejú, ijlú mašmanim», «vayaajilejá et hamán»; al `icré hamán, ela Hamán. Mikán lamadnu šestam źemán ajilá bePurim.

Comer, como diće el pasuc: «Anda come con alegría tu pan» $[E c l$ 9:7]. ¿Y de adónde que pan es se $u$ uá? Como ${ }^{/ 19}$ diće el pasuc: « ${ }^{\circ} \mathrm{Y}$ pan corazón de varón asufrirá» [Sal 104:15], y fue dicho: «Non sobre el pan a su solas yive el hombre» [Deut 8:3]; «andad comed gorduras ${ }^{76} »[\mathrm{Neh}$ 8:10], «y te hiźo comer a la magna ['maná']» [Deut 8:3]: no meldes ['leas'] la magna salvo Hamán. De aquí anỵeźimos que stam ['precisamente'] tienpo de comer en Purim.

En V850 (h. 4b) los párrafos explicativos de los dos primeros infinitivos שתול Siató / 'Beber' aparecen en párrafos seguidos; sigo la partición de J894h/j.-- En V850, como en Sal 104:15, לחם léhem 'pan' va precedido de la conjunción - ve- 'y' -y así también en J894j-,

${ }^{74} \mathrm{El}$ nombre inventado צחקיאל hay que ponerlo en relación con la raíz hb. צחק s.h.c 'reírse, burlarse'.

75 'Sacrificio pascual (...) ¿por qué? Porque pasó de largo el Creador ante las casas de nuestros padres en Egipto, que así dice el versículo: «Y diréis: "Éste es el sacrificio pascual para Dios (...)”»[Éx 12:27]'.

${ }^{76}$ Escrito גורסוראס gorsuras. 
conjunción que no aparece en J894h.- En V850 escrito תקרא ticrá 'leas' lo que en J894h es תיקרי ticré, con el mismo significado.- En J894j se pierde el juego de palabras del texto hebreo entre el nombre de Amán y el maná, cuyas consonantes coinciden en hebreo - המן Hamán / המן hamán- y sólo se diferencian en las vocales; para marcar tal diferencia, tales palabras aparecen vocalizadas en J894h.

27.- [Ceceña esta que nos comientes ¿por cavśa de qué? Por cavśa que no aḅasteció sus masas de muestros padres por levdarse (...), que ansí diće el pasuc: «Y cuećieron a la masa que sacaron de Ayifto torta ceceña que no levdó (...)» (S872 h. 20a $)^{77}$.]

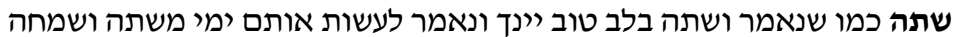

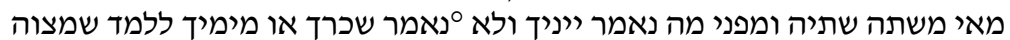

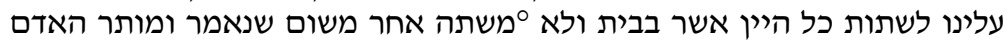

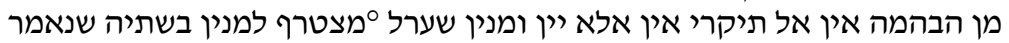
שתה גם אתה והערל ומנין שאין שיק שיעור לשתיה שנאמר שתו ושכרו ומיו וקיו.

Šató, kemó šeneemar: «Ušté beleb tob yeneja», veneemar: «La'asot otam yemé mišté vesimhá». ¿May mišté?: šetiyá. ¿Umipené ma neemar yeneja veló ${ }^{\circ}$ neemar šejreja o memeja? Lelamed šemiŝvá 'alenu lištot kol hayayin ašer babáyit velo ${ }^{\circ}$ mišté aḥer, mišum šeneemar: «Umotar haadam min haḅehemá ayin», lo ticré ayin ela yayin. ¿Uminayin še 'arel ${ }^{\circ}$ miŝtaref laminián bašetiyá? Šeneemar: «Šeté gam atá vehe'arel». ¿Uminayim šeén ši ‘ur lašetiyá? Šeneemar: «Šetú vešijrú uquíu».

Beber, como diće el pasuc: «Y bebe con corazón bueno tu vino» [Ecl 9:7]; y fue dicho: «Por haćer a ellos días de convite y alegría» [Ester 9:22]. ¿Qué es convite?: beber. ¿Y por qué fue dicho tu vino y ${ }^{\circ}$ no tu raquí ['aguardiente'] o tus aguas? Por enỵeźar ['enseñar'] que encomendanza sobre nos por beber todo el vino que en caśa y no ${ }^{\circ}$ bebraje otro, como diće el pasuc: «Y sobraje el hombre de la cuatropea nada» [Ecl 3:19], no meldes ${ }^{\circ}$ nada salvo vino. ¿Y de adónde que cerado ['incircunciso'] 'ajunta a la cuenta ['grupo'] en el beber? Como diće el pasuc: «Bebe también tú y el cerado» [Hab 2:16]. ¿Y de adónde que no hay caral ['medida'] al beber? Como diće el pasuc: ${ }^{\mathbf{2 0}}$ «Bebed y enḅorachad y gomitad» [Jer 25:27].

77 'Este pan ázimo que comemos ¿por qué causa? Porque no llegaron las masas de nuestros padres a fermentar (...), que así dice el versículo: «Y cocieron la masa sin levadura que sacaron de Egipto pan cenceño que no había leudado (...)» [Éx 12:39]'. 
Este נאמר neemar 'fue dicho' de J894h no figura en V850 (h. 4b) ni en J894j.- En J894h משתה mišté 'banquete' lo que en V850 es un más lógico משקה mašqué 'bebida', como también aparece en J894j.- En J894j se pierde el juego de palabras entre hb. אטין ayin 'nada' y "מרון yayin 'vino'.J894j traduce mal el reflexivo hebreo מצטרף mistaref 'se junta, se suma'.

28.- [Lechuga esta que nos comientes ¿por cavśa de qué? Por cavśa que amargaron los aicianos a vidas de muestros padres en Ayifto, que ansí dice el pasuc: «Y amargaron a sus vidas con servicio duro (...)» (S872 h. 20b) ${ }^{78}$.]

ורקוד כמו שנאמר להיות היהודים •עתידים ליום הזה •עתידים לא ${ }^{\circ}$ לאמר

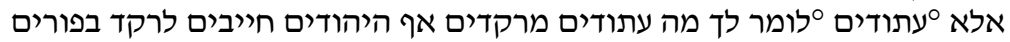

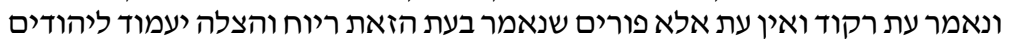

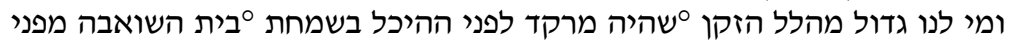
שכתוב ־ושאבתם מים בששון על אחת כמה וכמה מצוה עלינו לרקוד על היין.

Veracod, kemó šeneemar: «Lihyot hayehudim ` ‘atidim leyom haźé»; ' 'atidim lo ${ }^{\circ}$ neemar, ela ${ }^{\circ}$ 'atudim, ${ }^{\circ}$ lomar lejá: ma 'atudim meraquedim, af hayehudim hayabim leraqued bePurim. Veneemar: «'Et recod», veén 'et ela Purim, šeneemar: «Ba'et haźot révah vehaŝalá ya 'amod layehudim». ¿Umí lanu gadol meHilel haźaquén?, `šehayá meraqued lifné haHejal besimhat ${ }^{\circ}$ bet hašoebá, mipené šekatub: «Ušeabtem mayim besasón»; 'al aḥat kamá vejamá miŝvá 'alenu lircod 'al hayayin.

Y bailar, como diće el pasuc: «Por ser los jidiós ${ }^{\circ}$ aparejados al día el este» [Ester 8:13]; ${ }^{\circ}$ aparejados no ${ }^{\circ}$ está escrito, salvo ${ }^{\circ}$ margüecos ['maruecos, moruecos'], ${ }^{\circ}$ por enṿeźar: como margüecos bailan, tamién los jidiós obligados por bailar en Purim. Y fue dicho: «Hora de bailar» [cfr. Ecl 3:4], y non hora salvo Purim, como diće el pasuc: «En la hora la esta espacio y escapadura se aparaba a los jidiós» [Ester 4:14]. ¿Y quén a nos grande más de Hilel el viejo?, que era bailán delantre el Hejal ['Santuario’] en alegría de ${ }^{\circ}$ bet hašoebá ${ }^{79}$, porque está escrito: « $\mathrm{Y}^{\circ}$ apodaredeš

78 'Esta lechuga (= hierbas amargas) que comemos ¿por qué causa? Porque amargaron los egipciós la vida de nuestros padres en Egipto, que así dice el versículo: «Y amargaron sus vidas con duro trabajo (...)» [Éx 1:14]'.

${ }^{79}$ Literalmente 'casa de la extracción'; se refiere al manantial de Siloé, próximo a Jerusalén, donde el segundo día de la fiesta de Sukot se procedía a la extracción de agua que, mezclada con vino, se ofrendaba ante el altar del Templo. La compleja ceremonia se describe en TB-Suká 48a-49a y 51 y ss. La frase talmúdica completa sobre el regocijo de tal ceremonia aparece en TB-Suká 51a: «Todo el que no vio la alegría de la extracción del 
['sacaréis'] aguas con goźo» [Is 12:3]; sobre una cuanta más y cuanta más encomendanza sobre nos por bailar sobre el vino.

Efectivamente, en el versículo de Ester 8:13 la palabra está escrita 'twdym>, sin puntos vocálicos, palabra que corrige la masora en עת עתידים 'atidim 'dispuestos, preparados'; ello da pie al autor para rechazar la corrección masorética y mantener la grafía bíblica original de עתודים 'ath' 'atudim 'moruecos', así vocalizada en V850 (h. 4b); obviamente el juego de palabras se pierde en J894j.- En V850 נכמר nijtab 'está escrito', como

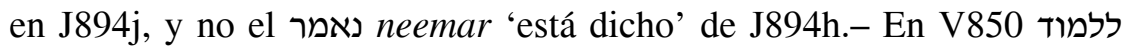
lilmod 'enseñar' -y así también en J894j- en lugar del לומר lomar 'decir'

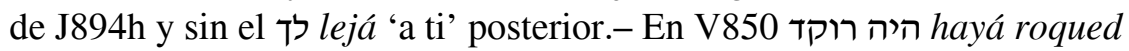
en lugar del היה מרקד hayá meraqued de J894h, con el mismo significado de 'había bailado'.- En J894j se pierde el juego de palabras de V850 y J894h entre השואבה hašoebá 'la extracción' -expresado en hebreo en J894j-, y שאבתם šeabtem 'extraeréis', que en J894j es apoderadeš.

29.- [En cada arnacio y arnacio es obligado el hombre por amostrar a sí miśmo como si él salió de Ayifto, que ansí diće el pasuc: «Y denuciarás a tu hijo en el día el este por dićir: "Por esto hiźo Yy a mí en mi salir de Ayifto», que no a muestros padres tan sólamente rigmió el Santo, bindicho él, salvo también a nos rigmió con ellos, que ansí dice el pasuc: «Y a nos sacó de ahí por traer a nos por dar a nos a la tiera que juró a muestros padres» $(\mathrm{S} 872 \text { h. } 20 \mathrm{~b})^{80}$.]

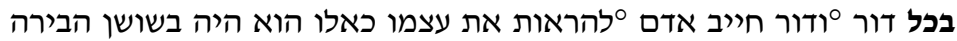

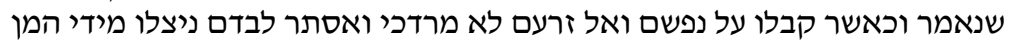

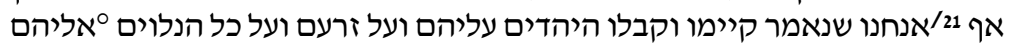

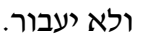

Bejol dor ${ }^{\circ}$ vador hayab adam ${ }^{\circ}$ leharot et aŝmó keilu hu hayá beŠušán habịíá, šeneemar: «Vejaašer quiḅelú 'al nafšam ve'al źar'am». Lo Mor-

agua del manantial no vio alegría en su vida'; y la propia del famoso sabio tanaíta Hilel el viejo, esta vez no inventado en nuestra parodia, queda plasmada en TB-Suká 53a.

80 'En cada generación y generación está obligado el hombre a considerarse a sí mismo como si hubiera salido de Egipto, ya que así dice el versículo: «Y contarás a tu hijo aquel día diciendo: "Por tal razón hizo el Señor en mi favor cuando salí de Egipto"» [Éx 13:8], que no libró el Santo, bendito sea, sólo a nuestros padres, sino que también nos libró a nosotros con ellos, que así dice el versículo: «Y nos sacó de allí para traernos (y) darnos la tierra que juró a nuestros padres» [Deut 6:23]'. 
dejay veEster lebadam niŝolu midé Hamán, ela af anaḥnu, šeneemar: «Quiyemú vequibelú hayehudim 'alehem ve'al źar'am ve'al kol hanilvim ${ }^{\circ}$ elehem veló ya‘abor».

En cada `ôerenancio ['generación'] es obligado el hombre ${ }^{\circ}$ por amostrar a sí miśmo como si él estuviera en Šušán el palacio, como diće el pasuc: «Y como recibieron sobre sus almas y sobre sus semen» [cfr. Ester 9:27 y 31] ${ }^{81}$. Non Mordejay y Ester a sus solas fueron escapados de poder de Hamán, salvo también mośotros, como diće el pasuc: «Afirmaron y recibieron los jidiós sobre ellos y sobre sus semen y sobre todos los ajuntantes ${ }^{\circ}$ sobre ellos y non pasará» [Ester 9:27].

En V850 (h. 4b) y en J894h דור ודור dor vador 'generación y לראות את Eeneración', pero en J894j se omite 'y generación'.- En V850 lir'ot et aŝmó 'verse a sí mismo', con el verbo en forma cal, lo que en J894h es להראות את עצמו lehar'ot et 'aŝmó en forma hif'il 'mostrarse a sí mismo'; no queda muy claro a cuál de las dos formulaciones se atiene J894j.- Este אליהם elehem 'a ellos' de J894h es en el versículo bíblico y en V850 עליהם 'alehem 'sobre ellos', y así también en J894j.

30.- [Por esto nos obligados por loar, por alabar, por alabar (sic), por afirmuśiguar, por enaltecer, por afirmuśiguar (sic) y por enšažar a quien que hiźo a muestros padres y a nos a todas las maravillas las estas (...). Y diremos delantre de Él: «Alabad a Yy» $\left(\mathrm{S} 872\right.$ h. 21a) ${ }^{82}$.]

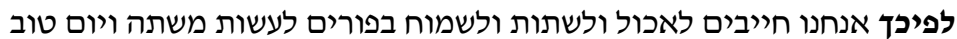

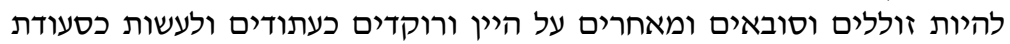

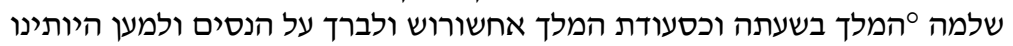

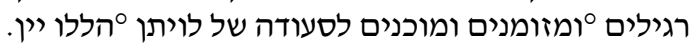

Lefijaj anaḥnu hayabim leejol velištot velismóạ̣ bePurim, la'asot mišté veyom tob, lihyot źolelim vesobeím umeaharim 'al hayayin veroquedim ka'atudim vela'asot kise‘udat Šelomó ohamélej beša‘atá,

${ }^{81}$ La formulación en V850 así como en J894h/j parece ser una mezcla de los dos versículos citados. Y así en Ester 9:27 se dice «[...] quiyemú vequibelú hayehudim 'alehem [...]» '[...] establecieron y recibieron los judíos sobre ellos [...]'; pero en Ester 9:31, a cuya formulación mayoritaria se ajusta la presente cita, no aparece el verbo quibelú 'recibieron' y sólo quiyemú 'establecieron'.

82 'Por tanto estamos obligados a dar gracias, a loar, a alabar, a glorificar, a ensalzar, a dar lustre, (a bendecir), a enaltecer (y a adorar) al que hizo a nuestros padres y a nosotros todas estas maravillas (...). Y digamos ante Él: «Alabad al Señor»'. He añadido entre paréntesis los verbos que omite S872 del texto de la Hagadá tradicional y pongo sic en lo que son repeticiones. 
vejis ‘udat hamélej Aḥašveróš, uleḅarej 'al hanisim. Ulema'an heyotenu reguilim `umeźumanim umujanim lis ‘udá šel Liviatán, `halelú yayin.

Por tanto nos obligados por comer y por beber y por alegrar en $\mathrm{Pu}-$ rim, por haćer conviite y día bueno, por ser tragones y enbriagos y tadrantes sobre el vino ${ }^{83}$ y bailantes como los margüecos y por haćer como se ‘udá de Šelomó ['Salomón'] ]4 ${ }^{84}$ el rey en su hora, y como se ‘udá del rey Ahašveróś ${ }^{85}$, y por bendećir «'Al hanisim» [“'Sobre los milagros»'] $]^{86}$. ${ }^{122} \mathrm{Y}$ por estarmos auśados ['acostumbrados'], 'prontos ['preparados'] y aparejados para se $u$ udá del Liviatán ${ }^{87},{ }^{\circ}$ alabad al vino.

En V850 (hs. 4b-5a) no aparece המלך hamélej 'el rey', que sí figura en J894h/j.- En V850 מזומנים meźumanim 'preparados' sin la conjunción ו ו ve- 'y' de J894h, que tampoco aparece en J894j.- Ese הללו "מנת halelú yayin 'alabad al vino' de J894h/j -según el inicio del párrafo siguienteen V850 es solamente הללויה haleluyah 'aleluya'.

31.- [Alabad a Yy, alabad siervos de Yy, alabad a nombre de Yy. Sea nombre de Yy bindicho de agora y hasta siempre. De onde esclarece el sol y hasta onde se pone alabado nombre de Yy. Alto sobre todas gentes Yy, sobre los cielos su honra. ¿Quién como Yy, muestro Dio?: el enaltecién por estar; el aḅaján por veer en los cielos y en la tiera. Alevantán de polvo mizquino, de muladares enaltece deśeośos, por haćer estar con jarifes, con ǰarifes de su pueblo. Haćién estar mañera de la caśa madre con hijos alegres. Alabad a Yy (S872 h. 21b) ${ }^{88}$.]

${ }^{83}$ Es decir, y prolongar la ingesta de vino.

${ }^{84}$ Se refiere al gran banquete que organizó Salomón tras la inauguración del Templo, según el relato de 1Reyes 8:65-66.

${ }^{85}$ El banquete de Asuero se describe en Ester 1:1 y ss.

${ }^{86} \mathrm{Se}$ trata de la bendición que comienza «'Al hanisim ve'al hapurcán» ('Por los milagros y por la salvación'), propia de la fiesta de Purim. Se recita antes de la lectura de la Meguilá y también se añade a la oración de la 'Amidá en la liturgia sinagogal de 'arbit ('noche'), šaḥarit ('mañana') y minḥá ('ofrenda', tarde) del día de Purim (14 de adar), entre las bendiciones que comienzan «Modim anahnu» ('Nosotros agradecemos') (bendición núm. 18) y Birkat hakohanim ('Bendición de los sacerdotes') que precede a «Sim šalom» ('Pon paz') (bendición núm. 19). Agradezco a mi querido sobrino Moisés Hassán estas últimas precisiones.

${ }^{87}$ Vid. supra nota 38 supra.

88 ' «Alabad al Señor, siervos del Señor, alabad el nombre del Señor. Sea el nombre del Señor bendito desde ahora para siempre. Desde salir el sol hasta su puesta sea alabado 


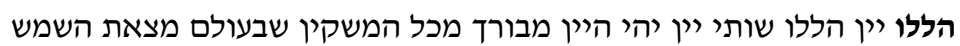

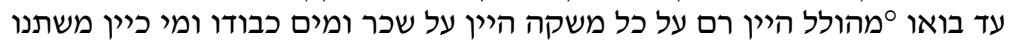

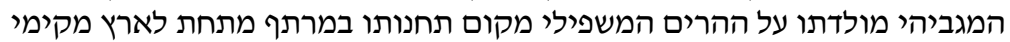

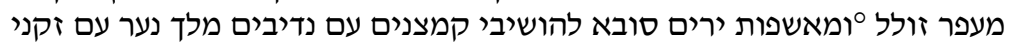
עמו מושיבי בחורים ובתולפת ירות יחדיו אחוזת מרעים קמצים שמחים הללו יין.

Halelú yayin, halelú šoté yayin. Yehí hayayin meboraj mikol hamašquín šeḅa'olam. Miŝet hašemeš 'ad boó ${ }^{\circ}$ mehulal hayayin. Ram 'al kol mašqué hayayin, 'al šejar umayim kebodó. ¿Umí kayayin mištenu?: hamagḅihí moladtó 'al heharim; hamašpilí mecom taḥanutó bemartef mitáhat laareŝ. Mequimí me 'afar źolel umeašpot yarim sobé, lehošibí camŝanim 'im nedibim, mélej ná'ar 'im źicné 'amó; mošibí baḥurim ubetulot yaḥdav, aḥuźát mere 'ím semeḥim. Halelú yayin.

Alabad al vino, alabad bebientes vino. Sea el vino bendicho más de todos los bebrajes que en el mundo. De salir el sol hasta su poner ${ }^{\circ}$ alabad y alabad con muestra boca. Alto sobre todo bebraje el vino ${ }^{89}$, sobre raquí y aguas su honra. ¿Y quén como el vino muestra bebienda?: el que haće alevantar su nacimiento sobre los montes; el que haće aḅajar lugar de su apośadura en magaćén debajo de la tiera. Haćién alevantar de polvo tragón, ${ }^{\circ}$ de muladares enaltece enbriago, por haćer asentar escasos ['avaros'] con šarefes ['nobles'] ${ }^{90}$, rey mozo con viejos de su pueblo; haćién asentar mancebos y muchachas a una junta de conpañeros alegres. Alabad al vino [cfr. Sal 113:1-9].

En J894h mehulal hayayin 'sea alabado el vino'; pero en V850 מללו ושבחו בפינו boca', que es lo que traduce J894j.- En V850, como en J894j, מאשפות meašpot ‘de muladares', sin la conjunción inicial - ו $u$ - ‘y’ de J894h.

32.- [En salir Yisrael de Ayifto, caśa de Ya'acob pueblo aladinán, hue Yehudá por su santidad, Yisrael su podestanía. La mar vido y fuyó, el Yardén se tornó atrás, los montes saltaron como barbećes, puestas

el nombre del Señor. Por encima de todas las gentes está el Señor, por encima de los cielos está su honra. ¿Quién es como el Señor, nuestro Dios?: entronizado en lo alto, se rebaja a mirar los cielos y la tierra. El que levanta del polvo al pobre, de muladares alza al menesteroso para que se siente con nobles, con los nobles de su pueblo. El que aposenta a la mujer estéril (como si fuera) gozosa madre de hijos. Alabad al Señor» [Sal 113:1-9]'. Estos salmos y los que siguen forman parte de la oración denominada Halel.

${ }^{89}$ Es decir, que el vino está por encima de cualquier otra bebida.

${ }^{90}$ El turquismo traduce hb. נדיבים nedibim 'generosos'. 
como hijos de ovejas. ¿Qué a ti, la mar, que te fuyes?, ¿el Yardén, que te tornas atrás? ¿Los montes saltedeš como barbećes; puestas como hijos de ovejas? Delantre Señor se adoloria tiera; delantre Dio de Ya'acob, haćién trastornar la peña pilares de aguas, pedrenal por fontanas de aguas (S872 hs. 21b-22a) ${ }^{91}$.]

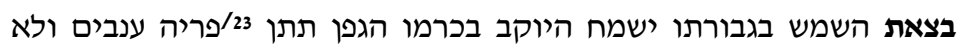

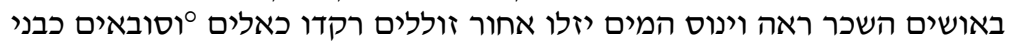

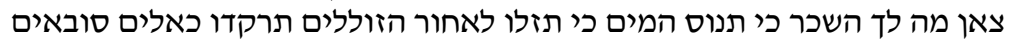

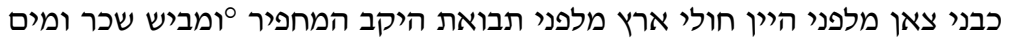

אוהביו מבזים למעינו מים. מלים.

Beŝet hašemeš bigburató yišmah hayoqueb bekarmó. Haġuefen titén piriah 'anabim veló beušim. Hašejar raá vayanós, hamayim yiźelú ahor. Źolelim raquedú jeelim ${ }^{\circ}$ vesobeím kibené ŝon. ¿Ma lejá hašejar ki tanús?; ¿hamayim, ki tiźelú leaḥor? ¿Haźolelim tirquedú jeelim; sobeím kibené ŝon? Milifné hayayin hulí, ereŝ; milifné tebuat hayéqueb hamaḥapir ${ }^{\circ}$ umab’iš šejar umáyim. Ohabav mebaźim lema'ayanó mayim.

En salir sol en su baraganía se alegra el lagador con su viña. La vid da fruto uvas y no agraz. El raquí vido y fuyó, las aguas se estillan atrás ['retroceden']. Tragones saltaron como barbećes y enbriagos como hijos de ovejas. ¿Qué a ti el raquí que te fuyes?; ¿las aguas, que estelláš atrás? ¿Los tragones saltáš como barbećes; enbriagos como hijos de ovejas? Delantre el vino adoloriyán ['duélete'], tiera; delantre de renovo del lagar el que haće arepudiar y ${ }^{\circ}$ avergüenzar raquí y aguas. Sus amigos menospreciantes a fuente de aguas [cfr. Sal 114:1-8 ${ }^{92}$.

En V850 (h. 8a) es siempre סבאים sebaím y no el סובאים sobeím de J894h, con el mismo significado de 'borrachos'.--El errado ומביש umabís de J894h está escrito correctamente en V850 ומבאיש umab'íš 'y hace avergonzar'.

${ }_{91}$ 'Al salir Israel de Egipto, la casa de Jacob de un pueblo de habla extraña, fue Judá santificado (como su heredad), Israel (como) su señorío. El mar miró y huyó, el Jordán se echó hacia atrás. Los montes saltaron ( $o$ bailaron) como cabritos, los collados como corderitos. ¿Qué tienes, mar, que huyes?, ¿Jordán, que retrocedes? ¿Montes, que saltastéis ( $o$ bailastéis) como cabritos; collados como corderitos? Ante el Señor tiembla, tierra; ante el Dios de Jacob, el que tornó la roca en piélago de agua, el pedernal en fuentes de agua [Sal 114:1-8]'.

${ }^{92}$ No figuran en V850 y tampoco en nuestros textos las bendiciones que siguen a continuación en la Hagadá tradicional sobre los alimentos simbólicos de la Pascua. 
[Ordenarán las meśas y comerán (...). Henchirán los vaśos de vino (...) (S872 h. 23a).]

$$
\text { אוכלים ושותים עד בלי די ומרקדים מעת }
$$

Ojelim vešotim 'ad belí day umeraquedim me 'at [ 'Comen y beben sin fin y bailan un poco' $]^{93}$

[Henchirán los vaśos de vino y dirá el Halel (S872 h. 24b).]

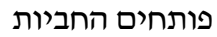

Potehim hahabiyot ['Abren los toneles']

33.- [Vierte tu saña sobre la gente que no te conocieron y sobre los reinos que en tu nombre non llamaron, que afinó a Ya'acob y a su morada desolaron (S872 h. 24b) ${ }^{94}$.]

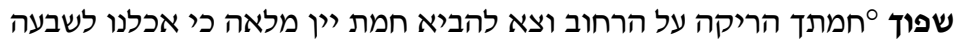
ועוד לא שתינו כחובתינו שפוך זעמך על המברים להבים וחרון אפך ישיג השכר תרדוף למבוף

ותשמידם מתוך הבית.

Šefoj `ḥematjá harecá 'al hareḥob veŝav lehabí ḥemat yayin meleá, ki ajalnu lesabea' ve'od lo šatinu kehobatenu. Šefoj źa'amjá 'al hamayim veḥarón apeja yasig hašejar; tirdof vetašmidem mitoj haḅáyit.

${ }^{124}$ Vierte ${ }^{\circ}$ tu saña la vaćía sobre la plaza y encomenda por trayer botija de vino llena, que comimos a hartura y inda no bebimos como muestro obligo. Vierte tu ira sobre las aguas y erecimiento ['enardecimiento'] de tu fulor ['cólera'] alcanzará el raquí; preseguirás y los destruirás de entre la caśa [cfr. Sal 79:6-7].

El traductor sefardí, que hasta ahora ha resuelto con bastante propiedad las trampas y juegos de palabras del texto de V850 -excepto cuando la traducción al judeoespañol hace imposible el mantenimiento de las voces hebreas-, sin embargo, no ha entendido aquí -y no le ha ayudado su texto

${ }^{93} \mathrm{Ni}$ en V850 ni en J894h/j figura la bendición de los alimentos que se pronuncia al final de la cena.

94 'Vierte tu saña hacia los gentiles que no te han reconocido y sobre los reinos que no han invocado tu nombre, que han devorado a Jacob y su morada han desolado [Sal 79:67]'. En S872 no figura la última frase habitual del parágrafo: 'Vierte sobre ellos tu cólera y que el furor de tu ira les alcance [Sal 69:35]; persíguelos con saña y destrúyelos bajo los cielos del Señor', que sí se parodia en nuestros textos. 
base, J894h, que no está vocalizado- el juego de palabras de V850 (h. 5a), donde no se trata del חמתך hamatjá 'tu ira' del texto de la Hagadá tradicional, sino de חמתך hematjá 'tu odre' o 'tu bota', con lo que su traducción de saña deja sin sentido el vacía que le sigue. Es decir, que lo que recomienda V850 al bebedor es que tire su odre vacío a la calle y que mande traer una cuba de vino llena.

34.- [Non por nos, Yy, non por nos, que a tu nombre da honra por tu merced y por tu verdad. ¿Por qué dirán la ĝente: «A dó agora su Dio»? Y muestro Dio en los cielos; todo lo que enveluntó, hiźo. Sus doladiźos plata y oro, hecha de mano de hombre: boca a ellos y no hablan; ojos a ellos y no veen; orejas a ellos y no oyen; nariź a ellos y no güeśman; sus manos y no apalpan; sus pies y no anda(n); no hablan con sus gargantas. Como ellos serán sus haćientes, todo el que se enfeućia en ellos. Yisrael, enfeućiadvos en Yy, su ayuda y su manparo Él. Caśa de Aharón, enfeućiadvos en Yy, su ayuda y su manparo Él. Temientes Yy enfeućiadvos en Yy, su ayuda y su manparo Él (S872 25a) ${ }^{95}$.]

לא לנו לעמוד מן השלחן כי עוד היום גדול ועוד אוכל בקערה והכיכוס והכוסות אינם

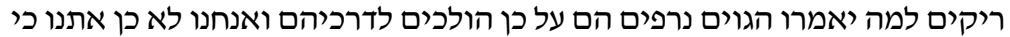

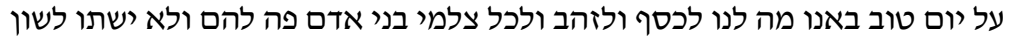

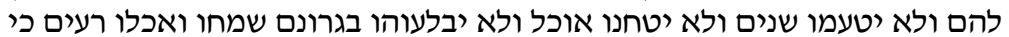
זמן אכילה הוא שתו ושכרו דודים כי יום יטלים פורים הוא.

Lo lanu la'amod min hašulhán, ki 'od hayom gadol ve'od ojel baque'ará vehakosot enam requim. ¿Lama yomerú haġoyim: «Nirpim hem; 'al ken holejim ledarkehem»? Vaanaḥnu lo jen itanu, ki 'al yom tob banu. ¿Ma lanu lekésef uleźahab ulejol ŝalmé bené adam?: pe lahem veló yištú; lašón lahem veló yit‘amú; šinayim veló yitḥanú; ojel veló yebal'uhu bigronam. Simhú veijlú, re‘ím, ki źemán ajilá hu. Šetú vešijrú, dodim, ki yom Purim hu.

95 'No a nosotros, Señor, no a nosotros, sino honra tu nombre por tu merced y por tu verdad. ¿Por qué dirán los gentiles: «Dónde está su Dios»? Y nuestro Dios está en los cielos; todo lo que desea, ha hecho. Sus ídolos (de los gentiles) son de plata y oro, obra de manos humanas: tienen boca y no hablan; tienen ojos y no ven; tienen oídos y no oyen; tienen nariz y no huelen; manos y no palpan; piés y no andan; no emiten sonidos con sus gargantas. Como ellos sean sus hacedores, todo el que confía en ellos. Israel, confíad en el Señor, que es su ayuda y su defensa. Casa de Arón, confiad en el Señor, que es su ayuda y su defensa. Los que temen al Señor confiad en el Señor, que es su ayuda y su defensa [Sal 115:1-11]'. 
Non a nos por alevantar de la meśa, que inda el día grande y más comida en el plato y los vaśos non ellos vaćíos. ¿Por qué dirán las gentes: «Flojos ellos, por tanto andan a sus caminos»? Y mośotros non ansí con mośotros, que sobre día bueno vinimos. ¿Qué a nos ${ }^{96}$ a plata y oro y a todos imaǵes ['imágenes'] de hijos de hombre?: boca a ellos y non beben; luenga ['lengua'] a ellos y non gustan; dientes y non molen; comida y non la engluten con sus garones [cfr. Sal 115:1-7]. Alegrad y comed, conpañeros, que tiempo de comer es. Bebed y enborachad, ${ }^{125}$ queridos, que día de Purim es.

35.- [Amí, que oyera Yy a yoź de mis rogativas (...). Arodeáronme dolores de muerte y angustia de ahuera me alcanzaron; angustia y ansia fallí y en nombre de Yy llamaré (...). Guardán torpes Yy: enprobecíme y a mí salva. Torna, mi alma, a tu holganza, que Yy gualadronó sobre ti, que escapastes mi alma de muerte, a mi ojo de lágrima, a mi pie de enpujamiento (...) (S872 hs. 25b-26a) ${ }^{97}$.]

אהבתי כי תשמע אזני קול קורא לאכול לחם אפפוני חבלי רעב ומצרי צמאון

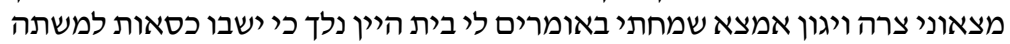

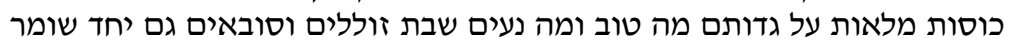

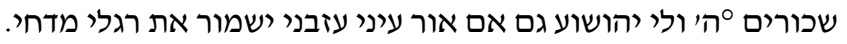

Ahabti ki tišmá‘ oźnai col coré leejol léḥem. Afafuni ḥeblé rá‘ab umeŝaré ŝimaón meŝauni, ŝará veyagón emŝá. Samaḥti beomerim li: «Bet hayayin nelej, ki yešbú kis'ot lamišté, kosot meleot 'al guedotam». Ma tob umá na ‘ím šébet źolelim vesobeím gam yáhad. Šomer šikorim ${ }^{\circ} H^{\prime}$ ' velí yehošía'. Gam, im or 'enay 'aźabani, yišmor et raglay mị̣eḥi.

Amí que oigan mis orejas yoź llamán por comer pan. Me arodearon dolores de hambre y estrechuras de sed me alcanzaron, angustia y ansia alcanzaré. Me alegrí en dićientes a mí: «Caśa del vino andaremos cuando se asentan sillas al conỵite, vaśos llenos sobre sus bodres». Qué bueno y hermośo estar tragones y embriagos también a una. Guadrán borachos ${ }^{\circ} \mathrm{H}^{\prime}$ y a mí salvará. También, si luź de mis ojos me dejará, guadrará a mis pies de enpuǰamiento ['tropiezo'] [cfr. Sal 116:1-8].

\footnotetext{
${ }^{96}$ Es decir, ¿qué nos importa?

97 'He amado (a Dios), que oyera el Señor la voz de mis ruegos (...). Me rodearon dolores de muerte y angustias de la tumba me alcanzaron; angustia y ansia encontré y el nombre del Señor invocaré (...). Guardián de simples es el Señor: enflaquecí y me ha salvado. Vuelve, alma mía, a tu reposo, porque el Señor te ha premiado, pues has librado mi alma de la muerte, mis ojos de lágrimas y mi pie de tropiezo [Sal 116:1-10]'.
} 
En V850 (h. 5b) la abreviación del nombre de Dios es "Yy y no el de $\mathrm{J} 894 \mathrm{~h} / \mathrm{j}$.

36.- [¿Qué responderé a Yy todos sus gualadrones sobre mí? Vaśo de salvaciones alzaré y en nombre de Yy llamaré. Mis prometas a Yy pagaré escuentra agora a todo su pueblo (...). Cortes de caśa de Yy entre ti, Yerušaláyim. Alabad a Yy (S872 h. 26a) ${ }^{98}$.]

מה אשיב ליין כל תגמולוהי עלי כוס ישועות אשא בעוד נשמה בבאפי נדרי ליין אשלם נגדה נא לכל שותיו בחצרות בית היין ערב ובקר וצהרים הללו יין.

¿Ma ašib layayin kol tagmulohí 'alay? Kos yešu 'ot esá be 'od nešamá ${ }^{\circ}$ beapí. Nedaray layayin ašalem negdah na lejol šotav. Behasisot bet hayayin 'éreb ubóquer veŝohoráyim hahelú yayin.

¿Qué tornaré a el vino todos sus gualadrones sobre mí? Vaśo de salvaciones alzaré en lo que alma ${ }^{\circ} \mathrm{en} \mathrm{mi} \mathrm{fulor.} \mathrm{Mis} \mathrm{prometas} \mathrm{['promesas']} \mathrm{al} \mathrm{vino}$ pagaré escuentra agora a todos sus bebientes. En cortes de caśa del ${ }^{26}$ vino tadre y mañana y siestas alabad al vino [cfr. Sal 116: 12-14 y 18-19].

En V850 y J894h באפי beapí 'en mi nariz', es decir, mientras haya aliento en mi nariz, mientras respire; el fulor de J894j es traducción no muy afortunada, que correspondería a un inexistente חרון אפarón apí 'mi cólera'.

\section{אין גומרים את ההלל בפורים משום מעשי ידי טובעים ביין ואתם אומרים שירה.}

En gomerim et haHalel bePurim mišum ma'asé yedé tobe 'ím beyayin veatem omerim širá. ['No se termina el Halel en Purim porque las manos se sumergen en el vino y decís una canción'.]

Tomará cada uno su vaśo en su mano y dirá ${ }^{99}$ :

98 ¿Cómo devolveré al Señor todas sus bondades para conmigo? Copa de salvaciones alzaré y el nombre del Señor proclamaré. Mis votos al Señor cumpliré ahora delante de todo su pueblo (...). En los atrios de la casa del Señor dentro de ti, Jerusalén, alabad al Señor [Sal 116: 11-19]'.

${ }^{99}$ Como advertíamos arriba, esta es la única indicación prescriptiva que aparece en judeoespañol y no en hebreo. En V850 se dice: «Haorḥim magḅihim kosam veomerim» 'Los invitados alzan sus copas y dicen'. 
37.- [Alabad a Yy toda gente, alabaldo todos los gentíos, que mayorgó sobre nos su merced y verdad Yy para sienpre. Alabad a Yy (S872 h. 26b) ${ }^{100}$.]

הללו את היין כל השותים שבחוהו כל הסובאים כי גבר טובו על כל המשקים

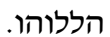

Halelú et hayayin kol hašotim; šaḅeḥuhu kol hasobeím, ki gabar tubó 'al kol hamašquim. Haleluhu.

Alabad a el vino todos los bebientes; alabad todos los enbriagos, que se mayorgó su mejoría sobre todos los bebrajes. Alabaldo [cfr. Sal 117:1-2].

38.- ['El año que viene en Jerusalén'. ${ }^{101}$

29/29

Como en V850 (h. 8a), sí figura tal frase en J894h (p. 29) -«Lešaná haḅaá ništé bejiflayim» 'El año que viene beberemos el doble'-, que, como he dicho arriba, no se traduce al judeoespañol.

\section{SingUlARIDADES DE LA VERSIÓN JUDEOESPAÑOLA}

En comparación con los textos hebreos de J894h y de V850, el texto judeoespañol presenta una serie de singularidades de las que me ocupo a continuación.

En lo formal, J894j coincide mayoritariamente en la partición de parágrafos con J894h (núms. 15, 17 y 25-26) ${ }^{102}$, pero en un caso (núm. 16) lo hace con V850 frente a J894h.

Más complejo es el tema de las variaciones textuales, en las que se pueden ejemplificar los siguientes fenómenos: 1) J894j y J894h vs. V850; 2) J894j vs. V850 y J894h; y 3) J894j y V850 vs. J894h.

100 'Alabad al Señor todos las gentes, ensalzadlo todos los pueblos, que acrecentó en nosotros su misericordia y verdad (es) el Señor eternamente. Alabad al Señor [Sal 117:1-2]'.

${ }^{101} \mathrm{La}$ frase, que en muchas hagadot figura en la parte final del texto, no está en el ejemplar de S872 que manejo, al que, como he dicho arriba, le faltan las hojas finales.

${ }^{102}$ Los números corresponden a los de mi edición. 
Siguiendo a su texto base -J894h-, encontramos en J894j las siguientes diferencias con V850:

1) Omisión de palabras (núms. 3, 10-11 y 12-14) y de partículas (núms. 1, 12-13, 24 y 28).

2) Adición de unas (núms. 11, 15 y 30) y otras (núms. 2, 7-8, 14 y 25).

3) $\mathrm{Y}$ formulaciones que no responden al texto original (núms. 1, 3, 5, 12 y 20$)$.

\subsection{J894j vs. V850 y J894h}

Resulta singular el texto de J894j frente a los textos hebreos -V850 y J894h- en lo siguiente:

1) Inevitable pérdida de los juegos de palabras al traducir al judeoespañol un texto hebreo (núms. 14 y 26-28, en este último caso en dos ocasiones, y 33).

2) Malas traducciones: unas veces debido a la no puntuación de J894h, lo que puede haber provocado el error del traductor sefardí (núms. 3, 5 y 33); pero en otras sin justificación aparente, ya que el texto hebreo no ofrece dudas (núms. 7, 13, 23, 27 y 36).

3) Omisión de partículas (núms. 5 y 13), palabras (núms. 4, 12 y 29) y frases (núm. 1).

4) Traducciones que no responden a los textos hebreos (núms. 2, 6, 9-10).

5) En una ocasión, mejor traducción del versículo bíblico citado (núm. 14).

6) Uso de un léxico diferente (núms. 1 y 14).

7) Y posibles errores gráficos (núm. 8).

5.3. J894j y V850 vs. J894h

De mayor interés son los casos en los que J894j coincide con V850 frente a su texto base, J894h. Veamos a qué fenómenos atañen tales diferencias. 
1) Desaparición de palabras (núms. 15, 25 y 27) y de partículas (núms. 17, 25 y $30-31)$.

2) Adición de palabras (núm. 16), de frases (núm. 17) y de partículas (núm. 26).

3) Diferencias léxicas (núms. 14, 19-21 y 28-29) y de formulación (núm. 31).

4) Y correcciones de errores de J894h (núms. 8, 21 y 27).

Ello me lleva a pensar que el traductor sefardí tuviera delante, no sólo la versión hebrea de la edición de Jerusalén, sino también alguna edición del texto hebreo de Hirsch Sommerhausen. Pero tal deducción deja sin explicación las otras diferencias que he señalado entre J894j y V850.

Por desgracia no puedo asediar con mis preguntas -y bien querría- a los editores jerosolimitanos que tanta guerra me han dado, pero también tanto placer, al haberme(nos) legado la versión judeoespañola aquí estudiada de esta magnífica parodia hebrea. 


\section{LISTA DE PALABRAS EXPLICADAS}

adoloriyar: núm. 32.- afilú (hb. אפילו): núm. 3.- Aḥašveróš (hb. אחשורוש): núm. 3.- Ajlán (hb. אכלן): núm. 19.- aĵuntar: núm. 27.- 'al: vid. hanisim.anchear: núm. 10.- anỵeźar: núm. 10; vid. tb. enyeeźar.- apararse: núm. 13.apoderar: núm. 28.- 'Aquibá (hb. עקיבא): núm. 5.- arodearse: núm. 4 y nota 24.- asetiguar: núm. 21.- asufrir: núm. 2 nota 14.- atemar: núm. 3.- auśados: núm. 30.- Bacḅuc (hb. בקבוק): núm. 4.- baldar: núm. 3.- bet hašoebá (hb. בית השואבה: núm. 28 nota 79.- cafrar (cfr. tc. kâfir 'infiel, ateo'): núm. 8.caral (tc. karar): núm. 27.- cerado: núm. 27.- cercución: núm. 13.- Criador: núm. 6 y nota 31.- cuenta: núm. 27.- daršar: núm. 5 y nota 26.- demudado: núm. 2.- deprender: núm. 14.- deprendimiento: núm. 10 nota 40.- embriagos: núm. 2.- enḅineyar (tc. bin-): núm. 23.- encomendanza: núm. 3 nota 19.enpuy̆amiento: núm. 35.- entremeter: núm. 7 y nota 33.- entremetidos: núm. 2.- enveluntar: núm. 13 nota 45.- enỵeźar: núm. 27; vid. tb. anyeźar.erecimiento: núm. 33.- escasos: núm. 31.- escuentra: núm. 6.- eśmoverse: núm. 23.- espartirse: núm. 7.- estillar atrás: núm. 32.- fulor: núms. 33 y 36.- Garg̉uerán (hb. גרגרן): núm. 3.- gerenancio: núm. 29.- grados: núm. 23.-

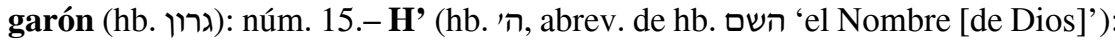
núm. 3.- habdalá: núm. 13 nota 46.- haḅirá (hb. הבירה): núm. 15.- hajamim (hb. חכמים): núm. 4.- Hamán (hb. המן): núm. 3.- Haamrán (cfr. arm. hamrá 'vino'): núm. 3.- hanisim: 'al — (hb. (על הנסים): núm. 30 y nota 86; vid. tb. nes.- Ḥarboná (hb. חרבונה): núm. 23.- Hejal (hb. היכל): núm. 28.- Hilel (hb.

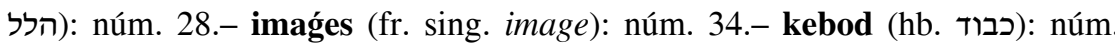
12.- kelal (hb. כלל ): núm. 8 y nota 35.- Liviatán (hb. לויתן): núm. 9 y nota 38.- limuño: núm. 5 y nota 28.- luenga: núm. 34.- magna (hb. מן): núm. 26.ma'asé (hb. מעשה): núm. 4.- manco: núms. 2 y 5.- margüecos (esp. sing. marueco, morueco 'cabrito'): núm. 28.- mašíạ (hb. משיח): núm. 5.- mayor: núm. 20.- Meg̉uilá (hb. מגילה): núm. 6.- meldar: núm. 26.- membraciones: núm. 11 .- menaŝeạ̣: núm. 15 nota 57.--Mordejay (hb. מרדכי): núm. 8.- mu(n) chiguar: núms. 3 y 13.- nes (hb. ס)): núm. 20; vid. tb. hanisim.- netifatí: núm. 5.- pará (tc. para): núm. 11.- Par'ó (hb. פרעו): núm. 20.- pasuc (hb. פסוק): núm. 5.- Pésạ̣ (hb. פס): núm. 7 y nota 34.- pleniśmo: núm. 6.- prometas: núm. 139.- prontos: núm. 30-- Purim (hb. פורים lit. 'Suertes'): núm. 3.- quiḍúš (hb. קידוש): núm. 13.- raḅí (hb. רבי): núm. 4.- raquí (tc. rakl): núm. 27.- rešut (רשות (רשו́): núm. 12.- regmición: núm. 13 nota 47.- rigmir: núm. 3.- Sabá 
(סבא (hb.-arm. núm. 4.- Ŝạaquiel: núm 25 y nota 74.- Šajrán (hb. שכרן): núm. 4.- sam (hb. שם): núm. 19.- šarefes (cfr. tc. sing şerefli): núm. 31 y nota 90.- Šelomó (hb. שלמו): núm. 30.- se'udá, pl. se'udot (hb. סעודות (סעודה): núms. 2 y 13.- stam (hb. סתם): núm. 26.- Šušán (hb. שושן): núms. 3 y 15 nota 58.- ta'anit (hb. תענית): núm. 11.- templados: núm. 10.- tirarse: núm. 11.Vaští (hb. ושתי): núm. 23.- Yehudá (hb. יהודה): núm. 16.- Yená (cfr. hb. יינאי): núm. 4.- Yisrael (hb. ישראל): núm. 2.- Źamrán (hb. זמרן): núm. 19.- źejut (hb. זכות): núm. 5.- źojé (hb. זוכה): núms. 9 y 13 y nota 49.

Recibido: 16/02/2012

Aceptado: 26/11/2012 